\title{
Music Technology, Gender, and Class: Digitization, Educational and Social Change in Britain
}

\author{
GEORGINA BORN and KYLE DEVINE
}

\begin{abstract}
Music technology undergraduate degree programmes are a relatively new phenomenon in British higher education, situated at the intersection of music, digital technologies, and sound art. Such degrees have exploded in popularity over the past fifteen years. Yet the social and cultural ramifications of this development have not yet been analysed. In looking comparatively at the demographics of both traditional music and music technology degrees, we highlight a striking bifurcation: traditional music degrees draw students with higher social class profiles than the British national averages, while their gender profile matches the wider student population; music technology degrees, by contrast, are overwhelmingly male and lower in terms of social class profile. We set these findings into analytical dialogue with wider historical processes, offering divergent interpretations of our findings in relation to a series of musical, technological, educational, social, political, and cultural-institutional developments in the late twentieth and twenty-first centuries. We ask what such developments bode for future relations between music, gender, and class in the UK.
\end{abstract}

\section{Introduction}

Recent decades have seen major changes in music education in Britain; things are in flux. The clearest manifestation of these changes is the establishment of music technology programmes, which have grown dramatically in the past fifteen years in both schools and universities in Britain. At a time when new higher education fee structures have raised serious questions

\footnotetext{
<georgina.born@music.ox.ac.uk>

The research for this article was funded by the European Research Council's Advanced Grants scheme, project number 249598, titled 'Music, Digitization, Mediation: Towards Interdisciplinary Music Studies' (2010-15). We are greatly indebted to Mark Taylor, whose quantitative and analytical skills were very important in relation to the data analysis, whose involvement in both the events held on the research was invaluable, and whose comments throughout were immensely helpful. We are also indebted to David Marquiss, who took charge of the early data collection and analysis. Mark Taylor and Mike Savage provided key comments on earlier drafts of this article, as did Andrew Barry, Anna Bull, Eric Clarke, Simon Emmerson, Lucy Green, Dan Grimley, Christopher Haworth, David Hesmondhalgh, Roger Parker, Christina Scharff, Jason Stanyek, and Robert Adlington, as well as Twentieth-Century Music's two anonymous reviewers. We warmly thank Michael Clarke, Simon Emmerson, Cathy Lane, Pedro Rebelo, Thomas Schmidt, and Simon Waters for their advice at earlier stages and on the design of the study. We are enormously grateful for all the comments, some of which stretched the demands on this research beyond what can be managed in a single article. We take full responsibility for the results of the iterative process of inviting and responding to comments. We hope that others will join us in pushing to a further stage of work on, and in adding further nuance to, the major issues raised by this article, some of which, regrettably, we have barely touched on. We hope also to initiate a constructive conversation among those engaged in, and managing, music in higher education in Britain and beyond about the critical questions raised by this research.
} 
about the value of a music degree, and when some university music departments face recruitment difficulties and others are under threat of closure, the apparent vitality of music technology undergraduate degree programmes is perhaps a sign of hope. Yet the social and cultural implications of this development, and of the particular demographics of students taking music technology degrees, have not yet been subject to analysis. In looking for the first time at the character of the student populations on such programmes, this article presents evidence of a possible cause for concern: the bifurcating demographics of what we will call traditional music (TM) degrees and music technology (MT) degrees in higher education (HE) in the UK. ${ }^{1}$ Our research shows that the student populations entering TM and MT degrees diverge markedly in terms of both their gender and their social class profiles, which raises the possibility that social differences may be being reproduced, amplified, or otherwise transformed through these developments in HE in music. We ask what such developments say about the present moment, how they relate to wider historical trends and existing theories of music, gender, and class, and what they bode for the future of music in the UK.

The research reported in this article stems from 'Music, Digitization, Mediation: Towards Interdisciplinary Music Studies' (MusDig), a five-year research programme funded by the European Research Council. Launched in 2010, MusDig has involved ethnographic case studies in the developing and developed worlds, as well as online ethnographic research, as the basis for analysing the far-reaching changes to music and musical practices worldwide afforded by digitization and digital media. ${ }^{2}$ One of the component research projects, led by Georgina Born, focuses on the present state of digital art musics ${ }^{3}$ in Britain, through ethnographic research on several leading centres in British universities as well as other key sites - festivals, conferences, gigs, and art events, along with funding bodies and other intermediaries. ${ }^{4}$ In the face of Born's sustained ethnographic observations, particularly about the gender of students taking MT degrees, we purchased a set of demographic data about the students entering MT degrees and related TM degrees from the Universities and Colleges Admissions Service (UCAS). The goal was not only to understand the demographic profile of students taking MT degrees, but also to probe the similarities and differences in this regard between related MT degrees and TM degrees. The UCAS dataset covers twelve institutions,

1 We recognize the risks of reifying these two metacategories of degrees, both of which are evolving and which have considerable variation within them. See the later discussion, and notes 3, 8, 10, and 96. The MT degrees, in particular, encompass a spectrum ranging from popular music production, studio, and sound recording courses to more art-oriented music technology and sound art or sonic arts courses. The primary ethnographic reference in this article is to the more art-oriented end of this spectrum.

2 On the MusDig research programme, see http://musdig.music.ox.ac.uk.

3 We use the term 'digital art musics' as a problematic placeholder for a space of contemporary genres associated with or departing from earlier electronic, electroacoustic, and computer art musics. The diversity of genres issuing from these earlier forms, and their unsettled classification (see Leigh Landy, Understanding the Art of Sound Organization (Cambridge, MA: MIT Press, 2007)), prompts us to create this encompassing term.

4 Fieldwork was also carried out in Montréal and Europe. Born's research is in dialogue with Patrick Valiquet's MusDig ethnography of digital art music scenes in Montréal, in which gender is one theme: Valiquet, “'The Digital is Everywhere”: Negotiating the Aesthetic of Digital Mediation in Montréal's Electroacoustic and Sound Art Scenes' (DPhil diss., University of Oxford, 2014). 
between them hosting thirty-eight degrees, for six demographic variables over a period of five years (2007-08 to 2011-12). The methodology used in the study is therefore hybrid, combining quantitative data analysis with both ethnography and wider related literatures in the service of what might be called a musical anthropology of the contemporary. ${ }^{5} \mathrm{~A}$ brief overview of the rationale for and limitations of the UCAS dataset introduces the analysis that follows.

Our aim in selecting the institutions involved in this study was to provide a broadly representative sample. ${ }^{6}$ We wanted to capture a range of programme types (from traditional music to music technology degrees) at a range of universities (from relatively elite, Russell Group members to 'post-1992' universities known for their music technology programmes) in all four nations (England, Scotland, Wales, and Northern Ireland). ${ }^{7}$ The various degrees were then grouped into three metacategories: traditional music (TM) degrees, music technology (MT) degrees with BA and BMus designations (MT: BA/BMus), and music technology degrees with BSc and BEng designations (MT: BSc/BEng). ${ }^{8}$ While not entirely satisfactory, this grouping affords general comparison between music and music technology programmes, as well as between them both and the national averages, ${ }^{9}$ while also allowing comparison within the music technology programmes between those oriented more to artistic and 'creative' practices and those oriented more to science and engineering. ${ }^{10}$ Conveniently, the tripartite grouping also produced three roughly equal-sized groups.

5 See Born, 'Lecture 5 - Ontologies and Interdisciplinarities' (Bloch Lectures, University of California, Berkeley, 3 November 2014), which is in dialogue with Paul Rabinow, Marking Time (Princeton: Princeton University Press, 2008). On the art-historical concept of the 'contemporary', which influences Born and Rabinow, see Peter Osborne, Anywhere or Not at All (London: Verso, 2013).

6 Because information about institutions and enrolments is potentially sensitive, we generalize our findings throughout. Our selection of universities and degree programmes was refined by consultation with six senior figures in the field (see our note of acknowledgements), and the resulting analysis was presented for feedback at events in May 2013 and July 2014. We carried out supplementary interviews with representatives from the universities in our sample. The research is complemented by and has its origins in Born's fieldwork and interviews with students and staff in some of the selected universities. Together, the ethnographic and interview research also give insight into the postgraduate music technology degrees (for which UCAS does not collect data).

7 The universities represented in the study are: Bangor University; University of Central Lancashire; De Montfort University; University of East London; University of Edinburgh; Goldsmiths' College, University of London; Huddersfield University; London College of Communication, University of the Arts, London; Manchester University; Queen Mary, University of London; Queen's University Belfast; and York University.

8 For an analysis of MT degrees, see Carola Boehm, 'The Discipline That Never Was: Current Developments in Music Technology in Higher Education in Britain', Journal of Music, Technology and Education 1/1 (2007). For an account from the perspective of student experience, see Julia Winterson and Michael Russ, 'Understanding the Transition from School to University in Music and Music Technology', Arts and Humanities in Higher Education 8/3 (2009).

9 Throughout, 'national average' figures cover all students who started university between 2007 and 2012, in all subjects: these data come from the Higher Education Statistics Authority (HESA).

10 The MT grouping is not unproblematic, and there are certainly other possibilities (e.g. production-based, popularmusic based, sonic arts-based). These are all generalizations and, despite checking with some care, we are aware as noted above (note 1) - that there may be as much variation within the categories as across them, just as all of the MT degrees - both BA/BMus and BSc/BEng - are interdisciplinary and combine, in some measure, both 'creative' and scientific elements. 
The UCAS demographic variables include gender, several indicators related to social class - all of which are discussed below - and ethnicity. ${ }^{11}$ The UCAS data on gender and ethnicity broadly confirm what Born observed ethnographically during her fieldwork. However, the data related to social class bring out demographic dimensions of the student population for the MT degrees that were not readily perceivable ethnographically, in this way extending and enriching the MusDig research. Regarding ethnicity, our data show that the fraction of black and minority ethnic (BME) students on TM degrees (about 6 per cent) is less than the national average for undergraduate students (about 11 per cent), and within this figure, black students are disproportionately even less likely to take TM degrees. MT degrees, however, in consisting of over 15 per cent BME students have a higher proportion than both the national average and, particularly, TM degrees. ${ }^{12}$ At the same time, the vast majority of students (well over 80 per cent) on all the degrees are white. Both the MT: BA/BMus and MT: BSc/BEng degrees therefore have a considerably stronger representation of BME students than the TM degrees; and within this, the BSc/BEng degrees have the strongest representation (16 per cent), particularly of black students. While these are striking findings, unfortunately the data allow very limited interpretation, and a fuller analysis would require additional research. ${ }^{13}$ We can therefore offer only tentative interpretations. On the one hand, that over 80 per cent of students are white seems to mirror the ethnic makeup of Britain's population. ${ }^{14}$ On the other hand, the figures of 6 per cent BME students for TM degrees and 15 per cent for

11 Unless otherwise noted, all figures given refer to student acceptances (and not applications). We checked application against acceptance figures and found that the demographics are broadly the same. We should note here two things about the precision of our figures. First, we only have aggregate data for the different degree types by each of these variables, which is to say that we do not have the microdata that would enable us to do close correlations between the variables. Second, for confidentiality reasons, UCAS is required to employ certain types of data suppression. This means that the information they provide is inexact when enrolment figures are particularly low, because doing otherwise might compromise student anonymity. The two problematic values for us were 'less than 3' and 'less than 5'. In order to make those figures statistically meaningful, 'less than 3' was numerically translated into 1.5 and 'less than 5 ' became 2.5. The reasoning behind these conversions, which we verified with UCAS, is that 'less than 3' means either 1 or 2 but not 0 or 3; likewise, 'less than 5 ' became 2.5, because the figure means either 1, 2, 3 or 4 but not 0 or 5 .

12 Note that the figures given for 'BME' include both BME and self-designated 'unknown' ethnicities. There are obvious problems with the UCAS classification of 'ethnicity' in the data: 'Asian' and 'black' are reductive and vague categories, while 'unknown' may encompass those who feel they do not fit into any given category, as well as those who (for political or other reasons) reject the entire exercise.

13 We are cautious about interpreting our data on ethnicity, hence our very limited analysis of this crucially important issue. First, at the level of individual degrees, there are exceptions to the figures we present. Certain degrees show much higher numbers of BME students, usually in universities in cities or urban regions drawing students from the local area and with high BME populations, while others are almost exclusively white. These exceptions seem to stem from particular institutional reputations and catchments rather than acceptance policies. Additionally, a significant proportion of students on MT courses selected 'unknown' ethnicity (for MT: BA/BMus degrees the figure is $c .7$ per cent). Given these uncertainties the overall picture is difficult to discern.

14 According to the 2011 Census, ' 48.2 million people ( 86.0 per cent of the population), reported their ethnic group as White ... Within this ethnic group, White British was the largest, with 45.1 million people (80.5 per cent)'. See www.ons.gov.uk/ons/rel/census/2011-census/key-statistics-for-local-authorities-in-england-and-wales/rptethnicity.html\#tab-Ethnicity-in-England-and-Wales. 
MT degrees might be taken to indicate that BME young people find both types of music courses to different degrees unattractive or antipathetic. To pursue this, it may be a case where a cultural-educational domain that is generally understood as ethnically unmarked or 'non-raced' - as representing the musical-universal, the 'commonality of humanity' in music - is actually experienced as ethnically white and as linked to an invisible politics of whiteness in the sense powerfully analysed by Richard Dyer, Vron Ware, Les Back, and others. ${ }^{15}$ But to reiterate: these are speculative interpretations. There is a need for further research on these critical and complex issues regarding ethnicity, as well as on their interrelations with gender and social class.

In the next part of this article we discuss the growth of the MT degrees and introduce a set of historical hypotheses attempting to account for such growth. We then present an analysis of gender differences between the MT and TM student populations, relating our findings to previous research with the aim of probing why this gender disparity exists. Following on, we pursue the findings on social class, setting out divergent interpretations of this material and what they augur in terms of wider cultural and social historical changes. As will become obvious, throughout the article there is an underlying methodological message: we aim to work against the conceptual fragmentation that is evident in many of the research areas related to our analysis - particularly in previous studies of music and class, which focus predominantly on consumption - and we advocate for linking such research to analyses of broader historical trajectories of musical, technological, educational, social, and political change.

\section{The rapid growth of music technology degrees: a nexus of multiple historical trajectories}

The entry of electronic and digital music technologies into university and classroom music teaching has been traced back to the late 1960s and early 1970s. ${ }^{16}$ However, the 1980s and 1990s mark a turning point. This is not only because of the proliferation from the early 1980s of affordable digital audio and consumer music technologies in the wider musical culture. It is also due to less obvious developments that between 1994 and 2012 catalyzed the emergence and exponential growth of the British MT degrees. In this section, we move outwards analytically in the attempt to show how the MT degrees have arisen and expanded in response to the synergistic interrelations between a series of distinctive, long-term trajectories of social, political, economic, technological, and musical change.

We begin with the rise of digital audio and consumer music technologies in the 1980s and 1990s. Intensifying uses of digital 'means of musical production', consumption, and circulation (especially from the mid-1990s with the growth of internet access), were matched by changes in the nature both of musical experience and of musical literacies. Paul Théberge,

15 See Richard Dyer, White (London: Routledge, 1997), 15; Vron Ware and Les Back, Out of Whiteness (Chicago: University of Chicago Press, 2002); Paula Rothenberg, ed., White Privilege (New York: Worth, 2011).

16 Virginia Caputo, 'Add Technology and Stir: Music, Gender and Technology in Music Classrooms', Quarterly Journal of Music Teaching and Learning 4/4 (1993-94), 87. 
in a foundational study, outlines how the expansion of digital music technologies itself significantly enhanced by the interoperability allowed from the 1980s by MIDI and the increasing affordability of digital synthesizers, samplers, and recording devices - was accompanied by profound shifts in musical practice. In particular, Théberge points to the appearance of a new musical formation defined by the elision of production and consumption - what has elsewhere been called 'prosumption' - as well as by related changes both in fandom and in aesthetic and affective sensibilities. ${ }^{17}$

In transposing Théberge's largely Canada- and US-based study into the British context, we note that, educationally, such developments were coincident with the introduction in 1998 of Music Technology AS and A2-level courses at secondary school level in Britain by the examinations board Edexcel. ${ }^{18}$ In marked contrast to the orthodox Music A-level curriculum, which focuses predominantly on composition and performance in the notated Western art music tradition of the past 400 years (with relatively less coverage of oral traditions, popular musics, and twentieth- and twenty-first-century art musics), the Music Technology A-level curriculum places less emphasis on literacy in music notation and performance training on an acoustic instrument. Instead, it is oriented to the use of computer-based sequencing and multitrack programs which are brought to the development of a vocabulary and an ear for sonic textures and arrangements primarily in relation to popular musics since 1900. As we observed through studying the content of these exams, a Music A-level exam might ask about figured bass in a flute sonata, while a Music Technology A-level exam is more likely to ask about the timbral treatment and stereo placement of a flute track in a pop or rock song. The contrast, then, is between Johann Sebastian Bach, on the one hand, and Belle and Sebastian, on the other. There is a clear difference in both the musical literacies and the musical canons being assumed, cultivated, and reproduced by the two A-levels. ${ }^{19}$

The explosive growth of university degree programmes situated at the intersection of music, digital technology, and sound was roughly coincident with the introduction of the Music Technology A-level. ${ }^{20}$ While student numbers in British HE grew during this period (the House of Commons Library reports a 75 per cent rise in degrees awarded between 1994 and 2011), these figures are dwarfed by the much larger increase in numbers of students

17 Paul Théberge, Any Sound You Can Imagine (Middletown: Wesleyan University Press, 1997). See also Théberge, 'Digitalization', in The Routledge Reader on the Sociology of Music, ed. John Shepherd and Kyle Devine (New York: Routledge, 2015). For a general discussion of 'prosumption', see George Ritzer and Nathan Jurgenson, 'Production, Consumption, Prosumption', Journal of Consumer Culture 10/1 (2010).

18 Edexcel is the only exam board to offer the Music Technology A-level. The A-level, or more properly the General Certificate of Education Advanced Level, is a school-leaving, pre-university qualification offered in Britain and other countries to 16 to 18-year-old school students. The qualification takes one year (AS) or two years (A2) to complete, with a set of exams at the end of the relevant year.

19 We recognize the limitations of this brief account of the curricula of the two A-levels and encourage further comparative research on them in relation to the larger themes of this article.

20 In fact the MT degrees developed slightly earlier: our figures indicate that student numbers on MT degrees began to take off from the mid- to late 1990s, while the MT A-level was introduced in 1998. 
taking MT degrees - which, according to data obtained from the Higher Education Statistics Agency (HESA), rose by nearly 1400 per cent between 1994 and 2011. ${ }^{21}$

Wider educational policies play a role in this history. When the Labour Party came to power in 1997 with its mantra of 'education, education, education', the expansion of British HE was well established. Overall HE participation rates had jumped from less than 4 per cent of the age appropriate population in 1950, to 19 per cent in 1990, to $c .40$ per cent by the mid-2000s. ${ }^{22}$ A significant factor in this apparently rapid growth from the early 1990s was the end of the Binary Divide in 1992, when vocationally oriented polytechnics were converted into independent degree-granting universities. Continuing these trends, in 1999 the Labour government announced a target of 50 per cent participation by 2010, which built on its earlier stated aims of an enlarged undergraduate population, more egalitarian access to $\mathrm{HE}$, and 'broader A-levels and upgraded vocational qualifications.' ${ }^{23}$ The advent of the MT degrees, given their openness to students seeking a music training without classical music qualifications and their wider range of entry qualifications than TM degrees (see below), clearly resonated with this policy agenda. Although not limited to this, MT degrees took hold rapidly in the post-1992 sector.

The 1990s also saw significant developments in economic and employment policy. From the 1980s the UK's economy had been restructured from an industrial and manufacturingbased one to a post-industrial, primarily financial, service, and knowledge-based economy. A new era began with the announcement from the later 1990s of Labour government policies intended to stimulate what was called a 'creative economy', with notions of 'creative industries' at the core. In this paradigm, writes Justin O'Connor, 'The cultural industries, previously ignored or lumped with "the Arts," were to become central to a new contemporary image for Britain and high-profile exemplars of the creativity and innovation that were to remake Britain for the 21 st century.' ${ }^{24}$

Coincidentally with their reconceptualization of what had been known as the cultural industries as 'creative industries', Labour introduced legislation to realize 'the potential of new

21 On the overall picture, see Paul Bolton's Parliamentary report, 'Education: Historical Statistics' (27 November 2012), 13-14. Our undergraduate figures were obtained from the 1994/95-2011/12 HESA Student Record and are based on the 1 December population, for comparability across all years. An information analyst at HESA ran a keyword search in the Student Record for enrolment in degrees with the following course titles: music and technology; or music and production; or music and comput; or music and sound; or music and sonic; or music and audio. As such, these figures approximate the growth of music technology and sound art degrees.

22 Bolton, 'Education: Historical Statistics', 14; Department for Business Innovation and Skills, 'Participation Rates in Higher Education: Academic Years 2006/2007-2012/2013' (London: Department for Business Innovation and Skills, 2014), 1. See also Miriam David et al., Widening Participation in Higher Education (TLRP and ESRC, 2008).

23 Quotation from British Labour Party, New Labour, New Life for Britain (London: Labour Party, 1996). This goal was not achieved: between 1999-2000 and 2006-2007 the actual per centage rose by only 0.6 per centage points, from 39.2 per cent to 39.8 per cent. See John Gill, 'Labour Concedes That It Won't Deliver Its 50\% Target On Time', Times Higher Education (17 April 2008), online.

24 Justin O'Connor, The Cultural and Creative Industries (London: Creative Partnerships, 2007), 48. For additional background, see Dave O’Brien, Cultural Policy: Management, Value and Modernity in the Creative Industries (London: Routledge, 2014). 
technology'. ${ }^{25}$ Effectively, the internet and other digital media were being conceived from the mid-1990s as burgeoning infrastructures for these developing industries. Indeed, O'Connor argues that the change of terminology from 'cultural industries' to 'creative industries' was hugely consequential, allowing for 'the identification of the creative industries with a "new economy" driven by "digital" technologies and closely related to the "information" or "knowledge" economy. It was the exploitation of intellectual property (IP) rights that was seen to provide the crucial link between these agendas - supposedly positioning the creative industries at the forefront of economic competitiveness. ${ }^{26}$

One effect of this network of developments - at once musical, technological, cultural, educational, political, and economic - was to create an opportune climate for the 'partial transformation of British universities through rubrics of ... creative economy, knowledge transfer, and interdisciplinarity - as these are equated with "innovation" and cultivating enterprise, with start-ups and spin-offs, partnerships with industry and government, public engagement, and student employability. ${ }^{27} \mathrm{MT}$ degrees instance aspects of each of these shifts: they are more open in terms of access; they operate in tandem with a broadened A-level (which tests a different skill set to the traditional Music A-level); and they have a somewhat vocational orientation, one that is distinctive from, broader, and more technologically oriented than the vocational orientation of TM degrees. Indeed, they are centrally concerned with technological training. And they are amenable to, or have an affinity with, creative industries initiatives, and appear oriented to cultivating creativity, innovation, and enterprise. In all these ways, the 1990s and after can been seen as an especially auspicious period for the growth of the MT degrees.

MT degrees appear, then, to embody one prominent institutional response to these propitious rubrics on the part of the university sector - perhaps the key institutional response in music in HE. This suggests a kind of inverse analysis to Boltanski and Chiapello's New Spirit of Capitalism. ${ }^{28}$ In essence, Boltanski and Chiapello argue that capitalist ideology and managerial discourse have since the 1970s appropriated and deployed to their advantage the modus operandi of a cultural realm that has traditionally been seen as an enemy of capitalism: artistic critique. The shifts outlined in this section evidence an equal but opposite reaction: how the arts, and notably music, have been conceived from the late 1990s as key repositories of entrepreneurial values, allied to expectations of economic growth and of boosting employment. ${ }^{29}$ For the confluence of reasons explored here, the MT degrees appear to be one major response on the part of the university sector to such shifts.

25 See British Labour Party, New Labour, New Life for Britain (London: Labour Party, 1996); British Labour Party, Britain Forward Not Backward: The Labour Party Manifesto (London: Labour Party, 2005).

26 O'Connor, Cultural and Creative Industries, 51.

27 Georgina Born, 'Creative Destruction: Electronic and Digital Art Musics in the UK in the Era of Creative Industries and Creative Economy', presented at Music and Digitisation: Industry, Institutions and Livelihoods (University of Oxford, March 2013).

28 Luc Boltanski and Eve Chiapello, The New Spirit of Capitalism (London: Verso, 2005).

29 For additional background, see Adam Behr, 'Cultural Policy and the Creative Industries', in The Routledge Reader on the Sociology of Music, Robert Hewison, Cultural Capital (London: Verso, 2014). 
A less obvious corollary of the synergistic developments outlined in previous paragraphs is how the shift from an industrial to a post-industrial economy fuelled a changing composition of the British labour force, threatening a large rise in youth unemployment. It is alongside these shifts in employment that governments of both right and left pursued policies oriented to stimulating rapid growth in HE student numbers. Whether these coincident processes were correlated - that is, whether the policies to increase HE student numbers were intended not only to produce a workforce suited to the creative or knowledge economy but also to mitigate the threat of youth unemployment - remains to be resolved. ${ }^{30}$ But given the exponential rise through the 1980s and 1990s of young people's engagement with electronic and digital 'means of musical production', and thus of autodidact electronic and digital music literacies - and add to this the catalyzing effect of Labour's creative industries paradigm, based on policy ideas for which music was arguably a core model ${ }^{31}$ - and the introduction of both the MT A-level and the MT degree programmes seems almost predictable. In this light, the accessible MT degrees appear to represent one way of combatting the threat of excessive youth unemployment by offering training oriented to the creative economy. Yet at the same time, and paradoxically, they portend risks identified as early as the 1980s by two major analysts of cultural industries policies, Nicholas Garnham and Bernard Miège, by fuelling the creation of what Garnham, with reference specifically to cultural labour, called a 'reserve army of the unemployed. 32

A complementary feature of the rapid growth of the MT degrees revealed by our demographic data is that they may contribute to combatting one of the key problems highlighted in recent $\mathrm{HE}$ and social policy: that of educational underachievement among white working-class boys. Since the 1990s, white working-class boys have been identified as underachievers in relation both to working-class girls and to working-class black and minority ethnic youth. ${ }^{33}$ While this issue has been a concern for educationalists and policy makers for a number of years, it was recently given added urgency due to the increasing uncertainties surrounding recruitment to undergraduate degrees in Britain following the

30 Here we note a divergence: Mark Taylor checked the statistical relationship between youth employment and rates of HE participation for the relevant decades and found no clear correlation. Our own view is that the coincidence of both trends suggests that, whether actualized or not, rising HE participation is likely to have been a political response to the threat of unacceptable levels of youth unemployment in this period.

31 See O'Connor, 'The Cultural and Creative Industries: A Critical History', Ekonomiaz 78/3 (2011), 35, where Sheffield's 'Creative Industry Quarter' is cited as exemplary. According to O'Connor, 'There is little doubt that the emergence of "independent" music ... in the 1970s was crucial for the experiments amongst [British] metropolitan authorities in culture-led urban regeneration', experiments that influenced 1980s GLC cultural industries policies, and thence the 1997 Labour government's creative industries paradigm (personal communication, December 2014).

32 See O'Connor, Cultural and Creative Industries, 26-8. O'Connor takes this phrase from Garnham's 1983 paper written for the GLC, reprinted in Nicholas Garnham, Capitalism and Communication (Sage, 1990). Miège's 1987 analysis points to the majority of cultural producers being 'almost permanently unemployed', along with a trend 'towards increased casualization': see Bernard Miège, 'The Logics at Work in the New Cultural Industries', Media, Culture and Society 9 (1987): 274-5. See also Nicole Cohen, 'Cultural Work as a Site of Struggle: Freelancers and Exploitation', tripleC 10/2 (2012), 148.

33 Emma Perry and Becky Francis, The Social Class Gap for Educational Achievement (Action and Research Centre, 2010). 
sharp hike in university fees in 2012. ${ }^{34}$ Given that, as we show below, students for MT degrees are primarily white, male, and from lower social class backgrounds, it might be argued that another reason for the expansion of these degrees is their apparent ability to attract and absorb what HE policy debate deems to be this problematic demographic. This suggests, again, that MT degree programmes appear, in part, to offer a means of mitigating excessive youth unemployment - while the risk is that they delay or convert the problem, by generating a reserve army of musical labour specifically among white working-class young men.

In parallel with this spate of historical developments, the wider twentieth-century musical culture was undergoing significant change. Indeed, the rapid growth of MT degrees represents a radical departure from TM degrees in terms of both music curriculum and the emergence and espousal of new canons, echoing the divergences apparent in the two music A-levels. Their growth responds to much longer arcs of twentieth- and twenty-first-century musical and cultural history involving: the expansion of sound recording, sound reproduction, and electronic music technologies; the work of early and mid-twentieth-century composers advocating a revolutionary expansion of musical and sonic materials - from Russolo and Varèse to Cage, Schaeffer, Stockhausen, Xenakis and beyond; the site-specific sound and sound installation works that developed from the 1960s in part under the aegis of postconceptual art; and the electronic and amplified sound materials characteristic of post-war popular musics. ${ }^{35}$ Across these multiple historical currents, music was reconceived in terms of what Varèse called 'organized sound'. The MT degrees thus both respond to and encourage an increasing engagement among young musicians and performers with the creative possibilities offered by the enlarged palette of musical and sonic materials provided by sound recording, electronic and digital manipulation and synthesis, including 'the microphenomena of musical sound itself'. ${ }^{36}$ The MT degrees had important precursors in this regard: a series of 'new' universities from the mid-1960s created music degrees that from the outset integrated electronic music with other sometimes new subdisciplines - music education, popular music studies, and ethnomusicology. York University inaugurated these developments, followed by City University and the University of East Anglia; and many of the senior figures in

34 Indeed, Richard Garner notes 'a massive slump in applications' particularly among white working-class boys ('Treat White Working-Class Boys Like Ethnic Minority', The Independent, 3 January 2013, online); while the Department for Business Innovation and Skills finds that the Higher Education Initial Participation Rate dipped nearly 5 per cent in the year that tuition fees increased ('Participation Rates in Higher Education', 1). Yet UCAS's own analysis of changes since the fee hike shows a complex pattern: certain student groups have increased, others have decreased and, overall, they suggest applications seem set to continue rising; see Mark Corver, 'UCAS Analysis Answers Five Key Questions on the Impact of the 2012 Tuition Fees Increase in England', November 2014, www.ucas.com/corporate/news-and-key-documents/news/ucas-analysis-answers-five-key-questions-impact-2012tuition. In this light, there remain at present contradictory interpretations of the effects of the 2012 fee rise.

35 See inter alia Jonathan Sterne, The Audible Past: Cultural Origins of Sound Reproduction (Durham, NC: Duke University Press, 2003); Peter Manning, Electronic and Computer Music (Oxford: Oxford University Press, 2013); Born, Rationalizing Culture: IRCAM, Boulez, and the Institutionalization of the Musical Avant-Garde (Berkeley: University of California Press, 1995); Chadabe, Electric Sound: The Past and Promise of Electronic Music (Upper Saddle River, NJ: Prentice Hall, 1997); Douglas Kahn, Noise, Water, Meat (Cambridge, MA: MIT Press, 1999); Christoph Cox and Daniel Warner, Audio Culture: Readings in Modern Music (London: Continuum, 2004).

36 Théberge, Any Sound, 186; Born, Rationalizing Culture; Kahn, Noise, Water, Meat. 
electroacoustic music involved in founding the MT degrees came through or helped to create these earlier programmes. In this light, the departures represented by the MT degrees at the turn of the twenty-first century might be seen as energizing nothing less than a widespread modernization of music in HE in Britain, catching up educationally with a vast terrain of combined technological, aesthetic, and conceptual developments in the decades since the Second World War, and addressing in various ways the challenges of integrating areas of music and musical discourse - art and popular, acoustic, electronic and digital - that have historically been disarticulated.

Finally in this section, we want to pinpoint one obvious worrying effect of these mutually modulating trajectories: the tendency towards a fetishistic technophilia in educational and policy discourses centred on technology, including those associated with creative industries. ${ }^{37}$ Such uncritical discourses pervade the Quality Assurance Agency for Higher Education's Music benchmark statement of 2008, which notes: 'Music technology is a constantly developing area requiring up-to-date equipment for creative work and recording. ${ }^{38}$ This directs us to the educational reverberations of the growth of the digital consumer music technology industry - an industry in which 'the incursion of capitalist [and consumerist] relations' into musical practice has long been wedded to sunny discourses of opportunity and promise. ${ }^{39}$ For rather than being led by existing musical needs, the expansion of the digital music technology industry was premised on the intensifying role of consumer music technologies as commercial intermediaries, or obligatory passage points, ${ }^{40}$ in musical practices worldwide, including music education practices. Indeed, in Born's ethnography, a senior academic figure in the field took the view that the very creation of 'music technology' as an educational category was partly 'perpetrated by manufacturers like Yamaha'.1 Our contention, then, is that the conjunction of technophilia and dependence on the digital music technology industry has been synergistic both with the rise of the creative industries paradigm and with neoliberal transformations in British universities; indeed, in some ways

37 For examples of such discourses in policy and education, see British Labour Party, New Labour, New Life for Britain; Darren Henley, The Importance of Music: A National Plan for Music Education (2011), 32, 36. For a similar critique in relation to digitization writ large, see Jonathan Sterne, 'Bourdieu, Technique and Technology', Cultural Studies 17/3-4 (2003), 368; Victoria Armstrong, Technology and the Gendering of Music Education (Farnham: Ashgate, 2011).

38 The statement goes on to accept as a matter of course that providing 'an adequate environment for the teaching and learning of music' places 'substantial demands' on resources. See Quality Assurance Agency for Higher Education, Music (QAA: Mansfield, 2008), 22.

39 Théberge, Any Sound, 255.

40 Bruno Latour, Science in Action: How to Follow Scientists and Engineers through Society (Cambridge, MA: Harvard University Press, 1987), 139.

41 The linking of the creation of new markets to music education has a longer history. Théberge shows how connections between the instrument manufacturing industry and educational curricula have existed since the late nineteenth century in relation to pianos, organs, and band instruments (Any Sound, 30, 32, 104). In his historical research on the MIDI protocol, Ryan Diduck argues that organizations like the North American National Association of Music Merchants (NAMM) capitalized on the ubiquitization of MIDI by promoting the large-scale incorporation of digital instruments into educational settings (Diduck, 'The 30th Anniversary of MIDI: A Protocol Three Decades On', Quietus (22 January 2013)). 
the MT degrees might be seen as the face of such neoliberalization in music in $\mathrm{HE} .{ }^{42}$ It is worth considering, then, the economic, musical, and other costs of the fetishism of the new as it links to a now-entrenched institutionalized dependence on music technology corporations. ${ }^{43}$

In accounting for the $c .1400$ per cent rise in the student numbers taking MT degrees between the mid-1990s and 2012, we have pointed to the confluence of an array of distinctive historical trajectories: technological, industrial, social, educational, political, and policyrelated, along with long-term musical changes. This nexus of synergistic historical forces fuelling the growth of the MT degrees in turn has a series of major emergent effects, which we now turn to consider. We do this initially through analysis of the demographic qualities of their student bodies with reference to gender and social class, in each case bringing our findings into dialogue with existing research.

\section{Gender and music technology degrees: musical toys for boys?}

Of all the demographic variables in our data, gender is the most alarmingly imbalanced: the student population across the various MT degree designations is nearly 90 per cent male. TM degrees, in contrast, show a more balanced gender profile, on a par with national student population averages: 55 per cent female to 45 per cent male. Although MT programmes accept more males in absolute terms, there is a slightly higher acceptance rate for women, which could indicate an awareness of - and even an attempt to redress - the gender imbalance. However, the significant bulk of male applicants, ${ }^{44}$ combined with the large number of places that have to be filled in each MT degree programme, suggest that there are not enough women applicants to reach parity between men and women at the level of absolute acceptances. A key problem, then, is the sheer lack of women applying. As such, it is the explosive growth of the MT degree programmes combined with women's relative lack of application to them that opens up the huge gender gap we have described. ${ }^{45}$

It is striking that at the border of secondary and tertiary education, a greater proportion of young women take MT A-level (17.5 per cent) than enrol in MT degrees (12 per cent). While our figures cannot explain why fewer women go on from MT A-levels to MT degrees

42 For a broader discussion of the conjunction of music, technology, and neoliberalism in academia, see Timothy Taylor, 'The Seductions of Technology', Journal of Music, Technology and Education 4/2-3 (2011).

43 Compare the Music benchmark statement with Philip Tagg's critical account of the futility and financial wastefulness of attempts to 'keep abreast of the stylistic and technological developments of the commercial music industry': Tagg, 'The Göteborg Connection: Lessons in the History and Politics of Popular Music Education and Research', Popular Music 17/2 (1998), 231. See also Born, Rationalizing Culture, 252-8, on problems caused by 'enforced' obsolescence and the resultant dependence on evolving corporate technologies in a leading public computer music research institute.

44 Our gross figures show over 11,000 men as opposed to under 1,400 women applicants to all the degrees researched over the five-year period of this study.

45 In a summarizing study of classical music professions and trainings which shows that gender inequality is not limited to digital music formations, Christina Scharff notes that 'women are [also] under-represented in positions of authority and prestige' in classical music. See Scharff, Equality and Diversity in the Classical Music Profession (ESRC, 2015), 5 . 
at university (although the higher acceptance rate suggests it is not because women are being disproportionately turned away by admissions processes), these figures invite comparison with a paradigm commonly used to describe the relatively weak representation of women in HE in science, technology, engineering, and mathematics (STEM) more generally: the leaky pipeline. $^{46}$

This paradigm probes the successively smaller participation of women in STEM from school age to university to postgraduate to professional career trajectory. If we start with the observation that the percentage of women taking MT A-levels is very low to begin with, recent research by Susan Hallam et al. suggests that the gender dynamics of music and technology are established well before the sixth form. ${ }^{47}$ Using data from the UK's Music Services, they show that the proportion of students aged 5 to 16 choosing 'music technology' as their instrument is about 40 per cent female (sometimes more). After age 16 this figure drops to 25 per cent, while among MT A-level entries the fraction of young women is 18 per cent. And, finally, at university enrolment on MT degrees they represent approximately 10 per cent. A leaky pipeline indeed. ${ }^{48}$ How can we make sense of these pronounced and cumulative gender disparities? In what follows we present three sets of arguments.

The first, as our reference to the leaky pipeline paradigm suggests, rests on the supposition that music technology is a microcosm of broader processes relating to women and technology. This is a common argument in different disciplines addressing gender and IT. Social psychologist Joel Cooper, for example, reviewing two decades of research on gender and IT, argues that 'women are not reaping the benefits of the technological revolution on a par with men', ${ }^{49}$ although slowly the 'digital divide' is becoming less pronounced and the pipeline less leaky. ${ }^{50}$ Overall, however, 'existing efforts to attract women to science have not worked, ${ }^{51}$ and women still display 'lowered interest, negative attitudes, lowered performance, and ... anxiety' when it comes to computers and digital technology. ${ }^{52}$ Judy Wajcman, a leading feminist scholar in science and technology studies, summarizes current thinking:

In contemporary Western society, the hegemonic form of masculinity is still strongly associated with technical prowess and power (Wajcman, 1991). Different childhood exposure to technology, the prevalence of different role models, different forms of schooling, and the extreme gender segregation of the job market all lead to

46 For a useful summary of this paradigm, see Jacob Clark Blickenstaff, 'Women and Science Careers: Leaky Pipeline or Gender Filter?', Gender and Education 17/4 (2005).

47 Susan Hallam et al. 'Gender Differences in Musical Instrument Choice', International Journal of Music Education 26/1 (2008), 12.

48 The figures for BTEC music qualifications, while not disaggregated for different music or music technology courses, also conform to the leaky pipeline model, with students being predominantly male: thus, total entrance to all music BTEC in 2012 was about 25,000, of which 30 per cent were young women. See www.edexcel.com/btec/news-andpolicy/Pages/BTECResultsDay.aspx (accessed May 2013).

49 Joel Cooper, 'The Digital Divide: The Special Case of Gender', Journal of Computer Assisted Learning 22 (2006), 321.

50 Blickenstaff, 'Women and Science Careers', 370.

51 Blickenstaff, 'Women and Science Careers', 370. See also Wendy Faulkner, 'The Technology Question in Feminism: A View from Feminist Technology Studies', Women's Studies International Forum 24/1 (2001).

52 Cooper, 'Digital Divide', 323. 
[what Cockburn (1983: 203) describes as] 'the construction of men as strong, manually able and technologically endowed, and women as physically and technically incompetent' ... Notwithstanding the recurring rhetoric about women's opportunities in the new knowledge economy, men continue to dominate technical work ... These sexual divisions in the labour market are proving intransigent and mean that women are largely excluded from the processes of technical design that shape the world we live in. ${ }^{53}$

We are persuaded by these arguments. But the question remains: why are these gender processes so subject to reproduction and resistant to change, when certain STEM domains - for example, medicine and the biosciences - have seen marked improvements in the professional representation of women? ${ }^{54}$ For our purposes, the leaky pipeline and similar research describe more than they explain the continuation of gender disparities in STEM.

A second set of analyses concerning gender comes from the sociology of music education. One is the theory of 'indirect discrimination' whereby, through classroom observations and other methods, it is possible to identify how gendered preconceptions enter into teachers' interaction with and assessment of school children in the music classroom. ${ }^{55}$ For example, boys' compositions and uses of technology tend to be lauded as testifying to natural ability, confidence, and creativity, whereas girls' are seen as conservative and traditional, and girls themselves as lacking in 'natural' ability. Such ideas also manifest more directly in discourses surrounding music, sometimes in the use of 'discrete critical vocabular[ies]' for men's compositions (described using signifiers such as 'virile' and 'powerful') and women's compositions ('delicate' and 'sensitive'). ${ }^{56}$ Indeed, Lucy Green, in her book Music, Gender, Education, traces similar discriminatory discourses effecting the exclusion of women composers from the music-historiographic canon as they pervade nineteenth- and twentiethcentury criticism. ${ }^{57}$

In her study, Green also describes a long history in which women have been marginalized in compositional practice as such. Part of this marginalization has to do with the construction of composition as a rational, cerebral and therefore 'masculine' pursuit, as opposed to the

53 Judy Wajcman, 'Feminist Theories of Technology', Cambridge Journal of Economics 34/1 (2010), 145. See also Georgina Born and Kyle Devine, eds, Contemporary Music Review (Special issue: 'Gender, Education and Creativity in Digital Music and Sound Art') (forthcoming 2015); Nelly Oudshoorn et al., 'Configuring the User as Everybody: Gender and Design Cultures in Information and Communication Technologies', Science, Technology and Human Values 29/1 (2004).

54 For one analysis of this widely observed phenomenon, see Elianne Riska, Medical Careers and Feminist Agendas (New York: Walter de Gruyter, 2001).

55 Notable studies are Lucy Green, Music, Gender, Education (Cambridge: University of Cambridge Press, 1997); Armstrong, Technology.

56 Robert Legg, "'One Equal Music”: An Exploration of Gender Perceptions and the Fair Assessment by Beginning Music Teachers of Musical Compositions', Music Education Research 12/2 (2010), 142.

57 Green, Music, Gender, Education, 96ff. On gender and the musical canon, see also Marcia Citron, Gender and the Musical Canon (Cambridge: Cambridge University Press, 1993); Ruth Solie, Musicology and Difference: Gender and Sexuality in Music Scholarship (Berkeley: University of California Press, 1995). 
apparently emotional and 'feminine' character of musical performance. Green identifies technical developments as pivot-points in these exclusionary processes:

Women's access to the kind of music education required for contemporary compositional developments originally became restricted at a time when the first major technical developments in music for centuries were rearing their heads in the shape of polyphony. Compositional activity after polyphony becomes increasingly separate from that of performance, requiring more control over instrumental technology and musical technique. ${ }^{58}$

Another theme in this literature is the gendered character of instrument choice. Scholarship on the topic tends to begin from the hypothesis that the general increase in women's social equality through the twentieth century should lead to a decreased gendering of musical instrument choice. ${ }^{59}$ Although there is evidence that the differences between stereotypically male and female instruments are becoming less pronounced, ${ }^{60}$ certain musical instruments and technologies are still predominantly associated with men, prominent examples being the electric guitar and the turntable. Explanations given for the continued male coding of certain instruments include design issues, role models, and received notions about acceptable public presentations of self. ${ }^{61}$ In particular, as Green notes, there are discursively constructed expectations that girls will 'avoid performance on electric or very loud instruments, especially those associated with popular music', while 'boys are depicted as flocking to these instruments. ${ }^{62}$ Instruments can thus serve as key avenues through which larger musical formations such as genres are constructed as gendered communities of practice. In this sense, digitization in music education extends a tradition in which men have dominated electronic and electroacoustic composition and instrumental performance both in the classical avantgarde and in technologically oriented popular genres such as rock, hip hop, and various dance musics. ${ }^{63}$ Of course, none of this is immanent in the materialities of sound or technology: characteristics such as electricity and loudness, which Green singles out as

58 Green, Music, Gender, Education, 113.

59 See, for example, Hallam et al., 'Gender Differences'; Hal Abeles, 'Are Musical Instrument Gender Associations Changing?' Journal of Research in Music Education 57/2 (2009).

60 Abeles, 'Gender Associations'.

61 Green, Music, Gender, Education; Hallam et al. ‘Gender Differences’; Monique Bourdage, “A Young Girl's Dream”, IASPM@Journal 1/1 (2010); Doubleday, 'Sounds of Power', Ethnomusicology Forum 17/1 (2008).

62 Green, Music, Gender, Education, 176. Gender bias is also evident in acoustic instrument choice, for example, among conservatoire teachers: see Scharff, Equality and Diversity, 12.

63 On the avant-garde, see Born, Rationalizing Culture; Tara Rodgers, Pink Noises: Women on Electronic Music and Sound (Durham, NC: Duke University Press, 2010). On popular genres, see Barbara Bradby, 'Sampling Sexuality: Gender, Technology and the Body in Dance Music', Popular Music 12/2 (1993); Mavis Bayton, Frock Rock: Women Performing Popular Music (Oxford: Oxford University Press, 1997); Sheila Whitely, Sexing the Groove: Popular Music and Gender (London: Routledge, 1997); Marion Leonard, Gender in the Music Industry (Farnham: Ashgate, 2007); Rebekah Farrugia, Beyond the Dance Floor: Female DJs, Technology and Electronic Dance Music Culture (Bristol: Intellect, 2012); Marion Leonard, 'Gender and Sexuality', in The Routledge Reader on the Sociology of Music. 
especially problematic for young women, are functions of history and culture; they are not inherently gendered. ${ }^{64}$

A further theme of the sociology of music education concerns the gendering of music classrooms as technological spaces. 'Often the spaces in which women are expected to compose', notes Victoria Armstrong, 'can seem alien. ${ }^{65}$ She observes that classroom music technology suites 'were consistently occupied by male pupils', while 'girls were more likely to be found in practice rooms, trying out ideas on the piano'. ${ }^{66}$ The male-dominated atmosphere of the technology suite made the space feel 'off-limits' to Armstrong's young female interlocutors. Such practices extend beyond the classroom, for the gendered discursive and spatial segregation and discrimination noted by Armstrong in the school technology suite has strong parallels in professional recording studios, in music retail, and even in the use of consumer audio in the domestic sphere. ${ }^{67}$ In sum, the cumulative insights from feminist science and technology studies and the sociology of music education suggest that while girls and women are no longer formally excluded from scientific and (music-)technological pursuits, they are subject to observable processes of gendered exclusion - occupationally, discursively, spatially, and practically. Such an analysis is consonant with Born's observations in her fieldwork on MT degrees.

A third set of arguments turn on gendered historiographies of sound, highlighting the materiality of music, sound, and technologies. Tara Rodgers, notably, has furnished a historical critique that portrays digital music technologies as extensions of a 'logic of controlling sound waves' that was established as a material-semiotic assemblage by the acoustic sciences. ${ }^{68}$ Rodgers outlines a "'network of analogies" that converged in epistemologies of electronic sound at the turn of the 20th century':

Acoustics experimenters and authors aligned the physical properties of sound waves with connotations of fluidity and excess that have been associated with female bodies throughout Western history and philosophy. To analyze and control sound meant to experience the pleasure and danger of unruly waves, and to seek their control

64 See, for example, Tara Rodgers 'Synthesizing Sound: Metaphor in Audio-Technical Discourse and Synthesis History' (PhD diss., McGill University, 2010); Kyle Devine, 'Imperfect Sound Forever: Loudness Wars, Listening Formations and the History of Sound Reproduction', Popular Music 32/3 (2013).

65 Armstrong, Technology, 119.

66 Armstrong, Technology, 119.

67 Keir Keightley, “'Turn it Down!” She Shrieked: Gender, Domestic Space and High Fidelity, 1948-59', Popular Music 15/2 (1996); Sara Cohen, 'Men Making a Scene: Popular Music and the Production of Gender', in Sexing the Groove: Popular Music and Gender, ed. Sheila Whiteley (New York: Routledge, 1997); Théberge, Any Sound; Leonard, 'Gender and Sexuality'; Carey Sargent, 'Playing, Shopping and Working as Rock Musicians: Masculinities in "De-Skilled” and "Re-Skilled” Organizations', Gender and Society 23/5 (2009). See also Anna Bull, 'The Musical Body: How Gender and Class are Reproduced Among Young People Playing Classical Music in England' (PhD diss., Goldsmiths College, University of London, 2014) on the subjectification and disciplining of the female body within the spaces of youth music orchestras.

68 Rodgers, 'Synthesizing Sound', 56. 
from a distanced perspective; both the objectified material of sound, and the subject position of acoustics researcher, were gendered in audio-technical discourse. ${ }^{69}$

In this light, it could be argued, the very epistemology of 'sound' that underpins the cultural origins of sound reproduction and manipulation - including today's digital music technologies - emerged from a historical conjuncture governed by a hegemonic rationalist masculinity locked in dualistic relation with its subordinate feminine Other. In a kind of strategic essentialism of sound and gender, research by Rodgers, Holly Ingleton, and Marie Thompson excavates long-standing historical associations between sounds and gendered cultural formations. ${ }^{70}$

Together, the three sets of arguments above suggest that the gendering of MT degrees can only be explained in terms of overlapping and synergistic historical processes: not just to do with gender and technology, but also how these continuously refract music-specific historical processes of gender discrimination. Indeed, in view of these several strands of argumentation, we find it persuasive that the gendering evident in our study might be understood as the evolving product of a double mediation in which the gendering of music composition is compounded by the gendered practices associated with digital technologies. Of course, in the historical context of a levelling off in the gender balance of TM degrees, after a period in which such degrees were predominantly 'feminine' pursuits, ${ }^{71}$ it may be that the overrepresentation of men in MT degrees represents simply a spike on the route to eventual parity. However, the MT degrees might also be exacerbating or entrenching a musicalized male hegemony, ${ }^{72}$ institutionalizing a future gendered division of labour in the music professions and in musical cultures more broadly.

\section{Social class: music degrees, class, and educational differentiation}

In addition to gender, our data register divergences in terms of the social class profiles of the student populations on TM and MT degrees. Before outlining these findings, it is necessary to note that social class, sometimes equated with socio-economic status (SES), is a difficult demographic variable to pin down. It has a number of competing definitions associated with distinctive sociological traditions. For this study, moreover, further challenges stem from UCAS's inability to release certain of their key data on class. ${ }^{73}$ When we asked

69 Rodgers, 'Synthesizing Sound', 56-7.

70 Holly Ingleton, 'Recalibrating Fundamentals of Discipline and Desire through the Automatic Music Tent', and Marie Thompson, 'Feminizing Noise', both papers presented to the gender panel of the New Instruments for Musical Expression (NIME) annual conference, 4 July 2013, held at Goldsmiths' College, University of London.

71 Green Music, Gender, Education.

72 John Shepherd, 'Music and Male Hegemony', in Music and Society: The Politics of Composition, Performance and Reception, ed. Leppert and McClary (Cambridge: Cambridge University Press, 1987).

73 UCAS collects information on university applicants such as parental education and occupational background. However, as this information is self-reported and entered in a free text field, which is then matched to a standardized list of National Statistics Socio-Economic Classification (or NS-SEC) indicators, the data are unverified and unavailable for analysis. 
UCAS which of the demographic variables regarding university entrance that they were willing to release related to social class, they directed us towards a five-tiered, postcodebased classification system called Participation of Local Areas (POLAR). POLAR indicates the likelihood that students from a particular postcode or region - allocated a 'quintile' score - will attend university. ${ }^{74}$ The higher the quintile ( 5 being highest), the more likely school students from that region are to attend some form of tertiary education. POLAR is not, then, a direct indicator of either social class or SES; moreover, it seems somewhat tautological as an indicator of social class amongst university applicants. So in an effort to provide a more robust picture of the social class profile of students entering MT and TM degrees, we analysed POLAR in conjunction with three other variables: the school type of students admitted, the overall A-level score of students admitted, and the nature of the music A-level taken (Music or Music Technology). Our 'social class' indicator is thus an alloy of several variables, ${ }^{75}$ none of which is on its own an ideal measure of social class; but they are each reasonable proxies, and by reading across them it is possible to approximate the social class profile of students entering the various music degrees.

POLAR attempts to capture relative degrees of advantage or disadvantage that result in variable rates of university attendance by region or postcode. Our findings are that TM degrees, although close to the national average, admit a greater proportion of students from POLAR quintiles 4 and 5, that is, those regions most likely to participate in $\mathrm{HE}$ and showing greatest relative advantage. The relative balance across the quintiles is inverted in MT programmes, and particularly the BA/BMus degrees, which admit more students from lower POLAR quintiles. ${ }^{76}$ Interestingly, while UCAS reports that the last ten years have seen $\mathrm{HE}$ participation increase across all quintiles, the greatest increase is found in the lower quintiles. ${ }^{77}$ While MT degrees resonate strongly with this trend, TM degrees do not.

In terms of school type, the data show that the representation of selective schools (i.e. grammar and independent schools) is much higher in TM degrees than in both MT programmes and the national average. Indeed, the MT: BA/BMus courses have a particularly low proportion of students from grammar and independent schools. ${ }^{78}$ The A-level exam results at admissions in terms of tariff (or point scores) are similarly differentiated between TM and MT degrees. TM degrees take a much lower proportion of students (under

74 See www.hefce.ac.uk/whatwedo/wp/ourresearch/polar/.

75 We prefer the analytical term 'social class' to SES, since class is widely understood in sociological theory today to include dimensions - notably the variable accumulation of cultural and educational capital - that may be occluded by a focus primarily on social and economic aspects of disadvantage and inequality, and that are particularly pertinent for assessing class position in relation to applicants for the two kinds of music degrees.

76 About 62 per cent of students on TM degrees come from the highest two quintiles ( 4 and 5), while about 50 per cent of students on MT degrees come from the lowest three quintiles (1, 2 and 3); of these, the MT: BA/BMus contingent is about 55 per cent, while the MT: BSc/BEng contingent is about 45 per cent.

77 UCAS, How Have Applications for Full-Time Undergraduate Higher Education in the UK Changed in 2012 (UCAS Analysis and Research, 2012), 2.

78 TM degrees take over 30 per cent of their students from grammar and independent schools, compared to approximately 5 per cent on the MT: BA/BMus designation. MT: BSc/BEng degrees take approximately 15 per cent of students from such schools, which is on a par with the national average. 
10 per cent) than the national average (approximately 25 per cent) with 240 points or less, and a considerably higher proportion (about 60 per cent) with 420 points or more (compared to the national average of 40 per cent). ${ }^{79}$ Almost opposite to this, the MT: BA/BMus degrees take a much higher proportion of students with 240 points or less (approaching 50 per cent - almost double the national average); and they accept a much lower proportion with 420 points or more (less than 25 per cent). Occupying a middle ground, the MT: BSc/BEng degrees take an above-average proportion of students with 240 points or less (about 30 per cent), and a lower than average proportion of students with 420 points or more (about 30 per cent). This is a strikingly polarized picture, which resonates strongly with the analysis of the differentiation of school type.

There are several key findings regarding Music and Music Technology A-level performance. ${ }^{80}$ The TM degrees have a strong requirement for Music A-level (c. 80 per cent of students admitted have this), and a small proportion of students admitted to them also have MT A-level (less than 10 per cent). In marked contrast, only a low proportion of students admitted to the MT degrees come with either Music or MT A-levels (c. 15 and 20 per cent, respectively). Almost 80 per cent of students on MT courses therefore appear not to have taken the MT A-level, and even fewer have taken Music A-level. This takes us to the limits of our data by raising the question of what qualifications and experience the students admitted to the MT degrees do have. ${ }^{81}$

In sum, compared to national averages, the students admitted to TM degrees tend largely to come from higher POLAR quintiles, attend selective schools at twice the rate of the national average, take Music A-level, and score considerably higher on their A-levels. ${ }^{82}$ In contrast, MT degrees have less competitive A-level entry requirements, draw a greater proportion of students from non-selective schools and lower POLAR quintiles, with few students who have taken either of the music A-levels. The TM degrees can thus be understood as comprising students with a higher social class profile than the national average, while MT degrees draw those with a relatively lower social class profile; although within the latter degree category students taking the MT: BA/BMus have a particularly pronounced lower social class profile,

79 The UCAS tariff point system assigns numerical values to A-level exam scores, so that $A^{*}$ is 140 points, $\mathrm{A}$ is 120 , and so on down to E, which is 40 points. To score 420 points or above, then, requires the equivalent of $A^{*} A^{*} A^{*}$ at A-level. The totals cited include AS and A2 level exam scores, with AS scores given half the A2 scores. Schools commonly encourage pupils to take additional qualifications in General Studies or Critical Thinking, which add further points.

80 Two points of explanation: 1) the data aggregate those students who took the two-year A2 course and those who took the one-year AS course for both Music and Music Technology. 2) The data also offer no way of discerning whether the figures represent the same or different students taking A-levels, that is, the same individual may have taken both Music and MT A-levels, or the figures may represent separate individuals.

81 Although we do not have data on this, anecdotal evidence suggests that BTECs are among the qualifications commonly proffered by these students.

82 Notably, Scharff's (Equality and Diversity, 7-8) analysis supports these findings, demonstrating the relatively high social-class profile of the classical music sector, including students and teachers at conservatoires as well as orchestral players (realms that are closely related to the TM degrees). See also Nicola Dibben's study of music at Sheffield University, 'The Socio-Cultural and Learning Experiences of Music Students in a British University', British Journal of Music Education 23/1 (2006). 
while students on the MT: BSc/BEng programmes appear to occupy an intermediate position. In both the TM and the MT degrees we therefore witness a kind of cluster effect associated with mutually reinforcing conditions that accrue to different positions in the social class spectrum. Our findings point clearly to a bifurcation in the social class profile of the students entering the two kinds of music degrees, as well as highlighting the role of music education today in mediating differences of social class.

In the last third of this article, we develop divergent interpretations of these stark findings on social class. The discussion is necessarily speculative: in addressing the implications of the material presented, we cannot resolve the contradictory analyses that follow. This is because at stake, just as in the earlier analysis of synergistic historical trajectories, are multiple dynamics for social and cultural change within which the development of the MT degrees are entangled, but to which they also contribute - dynamics that have the potential to catalyze alternative emergent directions. We therefore offer these interpretations in the spirit of an enquiry - a musical anthropology of the contemporary - that itself has the potential to influence the very processes it describes. In this sense we adopt a reflexive stance on this research and its possible impacts: the production of this analysis will, we hope and intend, feed into the ongoing fields that it addresses and may be formative of the futures that it attempts to discern. Indeed, one of our purposes is to offer the academic and educational MT and TM communities an analysis that includes future scenarios that may affect their futures.

\section{Music-educational futures: the entrenchment or transformation of social class through music?}

In analysing our material on social class, we face a sociological literature that has researched and conceptualized the relation between music and class mainly through patterns of consumption and taste formation among populations in countries of the global North. Although a recognizably sociological interest in such issues can be found in the early twentieth century, ${ }^{83}$ the touchstone for contemporary research is Pierre Bourdieu's study of French culture and class, Distinction: A Social Critique of the Judgement of Taste, first published in 1979. Bourdieu argued that there is a homology between the structure of social class and the differentiation of cultural tastes and practices, including tastes in music. In numerous realms of cultural consumption, and especially in music, he found strong associations between those of higher social class backgrounds and tastes for 'highbrow' cultural forms, while those of lower social class backgrounds gravitated towards 'lowbrow' cultural forms. Moreover, Bourdieu found that lower-class fractions are at a disadvantage because those of higher social class (who have greater amounts of cultural capital) are better positioned to influence the criteria for what counts as good taste. Bourdieu's analysis thus highlighted the role of differential access to and acquisition of cultural capital - in part through differences in forms and levels of education, as well as family socialization - in creating and reproducing wider class differences.

83 See John Mueller's 1935 paper, 'Musical Taste and How it is Formed', in The Routledge Reader on the Sociology of Music; and Karl Schuessler, 'Social Background and Musical Taste', American Sociological Review 13/3 (1948). 
Distinction has been both hugely influential and controversial. ${ }^{84}$ An especially significant set of challenges has centred on whether Bourdieu's analysis is generalizable beyond its immediate setting: France in the mid- to late 1960s. This was the starting point for a series of publications from the early 1990s by Richard Peterson, who conducted broadly similar analyses using US survey data. In essence, Peterson corroborated the basic thesis of Bourdieu's study: social class distinctions based on differential access to cultural capital are at work in the musical field. Yet Peterson's interpretation contained a subtle but critical difference: he argued that the musical tastes of privileged social classes, in contrast to the exclusive and 'univorous' proclivity for art music identified by Bourdieu in 1960s France, were marked by openness, diversity, eclecticism, and cosmopolitanism. ${ }^{85}$ Such eclectic tastes, Peterson observed, were more constitutive of high cultural capital in music in the US context in the 1990s. This interpretation has become known in cultural sociology as the 'omnivore thesis. ${ }^{86}$

The omnivore thesis is by no means universally accepted; indeed, it has generated substantial debate. A number of theoretical and methodological queries have been voiced, ranging from incorrectly conflated homological relations between status and class, ${ }^{87}$ to the challenge of eliciting the qualitative dimensions of preference and participation patterns using quantitative surveys, ${ }^{88}$ to the problem of over-simplified genre categories and the idea that omnivorous taste patterns are an effect of method. ${ }^{89}$ Particularly important among efforts to test and expand upon both Bourdieu's analysis and the omnivore thesis was the Cultural Capital and Social Exclusion Project, which aimed to update Distinction's methodology for twenty-first-century Britain. The resulting landmark book, Bennett et al.'s Culture, Class, Distinction (2009), considerably nuances Bourdieu's study. Like Bourdieu, the British study found music to be an especially intense field of taste differentiation; indeed, music was 'the most divided, contested' field of cultural practices researched. ${ }^{90}$ However, unlike the primarily

84 Here we touch on a particular set of criticisms of Bourdieu's work. There are many others, which take Distinction more or less centrally as their starting point: see, for example, Bruno Latour, Reassembling the Social: An Introduction to Actor-Network-Theory (Oxford: Oxford University Press, 2005); Antoine Hennion, 'The Price of the People: Sociology, Performance and Reflexivity', in Cultural Analysis and Bourdieu's Legacy: Settling Accounts and Developing Alternatives, ed. Elizabeth Silva and Alan Warde (London: Routledge, 2010); Georgina Born, 'The Social and the Aesthetic: For a Post-Bourdieuian Theory of Cultural Production', Cultural Sociology 4/2 (2010); Luc Boltanski, On Critique: A Sociology of Emancipation (Cambridge: Polity, 2011); and regarding music, see Antoine Hennion, 'Those Things That Hold Us Together: Taste and Sociology", Cultural Sociology 1/1 (2007).

85 Richard Peterson, 'Understanding Audience Segmentation: From Elite and Mass to Omnivore and Univore', Poetics 21/4 (1992).

86 Certain scholars suggest that the omnivore thesis is a viable interpretation even in the French context. See Philippe Coulangeon and Yannick Lemel, 'Is "Distinction" Really Outdated? Questioning the Meaning of the Omnivorization of Musical Taste in Contemporary France', Poetics 35/2-3 (2007), 107, which argues for a positive correlation between education and omnivorousness in musical tastes.

87 Tak Wing Chan and John Goldthorpe, 'Social Stratification and Cultural Consumption: Music in England', European Sociological Review 23/1 (2007).

88 Will Atkinson, 'The Context and Genesis of Musical Tastes: Omnivorousness Debunked, Bourdieu Buttressed', Poetics 39 (2011); Rimmer, 'Beyond Omnivores and Univores', Cultural Sociology 6/3 (2012). See also Hennion, 'Those Things'.

89 Atkinson, 'Musical Tastes'.

90 Bennett et al. Culture, Class, Distinction (London: Routledge, 2009), 75. 
class-based analyses that defined Bourdieu's work and the omnivore debate, the British researchers additionally highlight the roles of age, ethnicity, and gender in the differentiation of cultural practices. In terms of the character of those differentiations, Bennett et al. found a strong clustering in the appreciation for Western art musics, and another cluster for popular musics. Although this division was articulated along lines of class and education, age was the strongest indicator. ${ }^{91}$

Mike Savage and Modesto Gayo, in a recent paper extending Culture, Class, Distinction, dispute the omnivore thesis by insisting that in contemporary Britain, at least, the debate on the omnivore has distracted us from examining the profoundly divided nature of musical taste. ${ }^{92}$ Extending their analysis of consumption, they go on to suggest a major conceptual reorientation that resonates with our own work: 'Rather than people changing their musical taste and ranging across more musical genres, we are seeing the reworking of the boundaries of musical genres themselves. What we are seeing today could be a fundamental remaking of the musical canon, in which the historic investment in classical music as the dominant position in the musical field is being reworked. ${ }^{93}$ While Savage and Gayo suggest that the 'field analytical perspective' developed in their article makes it possible to 'recognize the wider historical patterns of musical production, institutionalization and mediation' at the basis of such shifts, in this article their argument is not fully worked through. In what follows, we pursue and deepen their opening move by etching the contours of an analysis of wider institutional and aesthetic changes in relation to our earlier findings on music in HE as it mediates social class.

Despite the evident importance of discussions of the shifting articulation between 'highbrow' and 'lowbrow' in music consumption, the post-Bourdieu and omnivore debates have paid scant conceptual or empirical attention to how such shifts are being affected by the changing tenor of the institutionalized valorization of the distinction between 'high' and 'low' in music. Thirty-five years ago, this distinction and its presumption of a fundamental difference in the value and legitimacy of art musics and popular musics was being resiliently reproduced by the major British cultural institutions for music: educational institutions (schools, conservatoires, universities), media institutions (the $\mathrm{BBC}$ ), and performance institutions (concert halls, music festivals, opera houses). But today, due no doubt to longterm cultural processes (including expanding media coverage of popular musics, the BBC's search for popularity in its music coverage, and the growth of new forms of popular and critical discourse, knowledge, and competence about popular musics fuelled by their increasing ubiquity) that have engendered widespread identification with and valorization of a vast range of popular musics, there has been both a flattening of the difference - in that certain popular musics are now routinely subject to public valorization and critical appreciation,

91 Bennett et al., Culture, Class, Distinction, ch. 5. See also Mike Savage, 'The Musical Field', Cultural Trends 15/2-3 (2006); Mike Savage and Modesto Gayo, 'Unravelling the Omnivore: A Field Analysis of Contemporary Musical Taste in the United Kingdom', Poetics 39 (2011), 342, 345.

92 Savage and Gayo, 'Unravelling', 353.

93 Savage and Gayo, 'Unravelling', 353. See also Annick Prieur and Mike Savage, 'Updating Cultural Capital Theory: A Discussion based on Studies in Denmark and in Britain', Poetics 39 (2011). 
while classical music has itself become subject to populist currents (e.g. in the rise of radio station Classic FM) - and yet also a continuation of the institutionalized distinction between 'high' and 'low' music repertoires, not least in music in HE. It is this evolving situation that Born encountered in her fieldwork on music in HE, along with clear signs that the historical settlement is in the process of change. The puzzle thrown up by this reality, which the focus solely on consumption in earlier research evades, is that of the relationship between shifting patterns of consumption, on the one hand, and the changing institutionalization of differences in the valorization of art and popular musics, on the other - particularly as they surface in music education, since along with popular media and the internet, music education also plays an influential role in forming musical tastes and competencies among sections of the population. In this last part of the article, we aim to stimulate the beginnings of a discussion on this crucial and neglected issue.

While the post-Bourdieu and omnivore debates covered important ground, then, from the perspective of this study they have been constrained by insufficient attention to wider social and historical developments, including aesthetic, educational, and culturalinstitutional changes that must bear some relation to the trends uncovered by studies of music consumption. We turn now to two divergent and speculative interpretations of the potential emergent effects of the dynamics evident in our research as a contribution to opening out the debate on music and social class formation to encompass such aesthetic, educational, and cultural-institutional changes.

\section{Negative interpretations}

We offer, first, a set of negative interpretations based on the possibility that the two kinds of music degrees, MT and TM, participate in the reproduction or intensification of social class differences through music. Thus, while we have clear evidence of the differentiation by class of those entering the two degrees, the educational experiences offered by the two degrees, and their cultivation of particular and divergent musical literacies and competencies, subjectivities and tastes, might well be understood as further augmenting or entrenching the relative class trajectories and future life chances of their different student populations. ${ }^{94}$ The point is that our research on higher education shows the mediation by music of social class formation in process: on the one hand, at degree entry, how individuals' earlier class formation and educational provision influence the kind of music degree that is taken; on the other hand, over the course of the degree experience and its influence on musical literacies and subjectivities, how music education is likely to mediate individuals' post-degree class trajectory.

What we see, then, is the dynamic production of social class position in childhood and young adulthood through music: for children from advantaged social backgrounds, a) the existence of high cultural capital (in musical and other spheres) through family

94 While it would be valuable here to engage with research on the post-degree employment and lifecourse trajectories of students from both kinds of degrees, we do not have those data. This would be a very productive additional research project for the community of music in British HE. 
socialization and upbringing is compounded by b) privileged schooling and a Western art music curriculum, including access to traditional musical literacy, instrumental music training, choir, orchestra, and so on, and then further by c) A-level choice, including the ability to take Music A-level; and this can lead to d) success at entry into the elite universities and their TM degrees. The system amounts to a self-reinforcing dynamic of the reproduction (or attainment for students from families buying their way into educational advantage via selective schools) of higher social class position associated with high cultural capital in music, ${ }^{95}$ and - importantly - a relatively unchanging relation to the historicist canon in music, itself being propounded and reproduced in the elite universities' TM degrees. ${ }^{96}$

In this account, Western art music, the core of the curriculum in TM degrees, is correlated with a student population having higher social class and higher cultural capital than those studying the MT degrees both at entry and at exit. That is to say, the bifurcation of the student population taking MT and TM degrees correlates with the intensification of differences in cultural capital, and thus the augmented reproduction of class differences, through the degrees' fuelling of students' training and competence in the divergent musics offered by the two kinds of curricula, and thus students' differential access to and acquisition of cultural capital in music - as it is still institutionally defined, with qualifications given below.

Such an interpretation is reinforced by the pronounced hierarchy evident in the institutionalization of the two degrees and their curricula within the British university system: the TM degrees largely occupying the elite end of the university spectrum, along with several of the most prominent music conservatoires, which are emblematic of the high end of TM training in musicology, performance, and composition; while the MT degrees have, with key exceptions, developed mainly at the lower status end of the university spectrum among the 1960s and, in particular, the 'post-1992' universities. ${ }^{97}$ In this sense the MT degrees are in their very institutionalization, their academic location, subordinate in status and legitimacy to the TM degrees.

95 See also Dibben, 'Socio-Cultural and Learning Experiences'; Bull, 'The Musical Body'; Katherine Butler Brown, 'The Social Liminality of Musicians: Case Studies from Mughal India and Beyond', Twentieth-Century Music 3/1 (2007). For an important general analysis of the centrality of attendance at elite universities for higher social class positions, including upward social mobility after graduation, see Paul Wakeling and Mike Savage, 'Entry to Elite Positions and the Stratification of Higher Education in Britain', Sociological Review (forthcoming 2015).

96 Although we characterize TM degrees as based primarily on a historicist canon of Western art musics, we acknowledge that they are evolving. In recent decades ongoing attempts have been made, to variable effect, to include representation of popular and non-Western musics, as well as popular music studies and ethnomusicology, due in part to the influence of the reflexive critiques enunciated by 'critical' and 'new' musicology from the late 1980s on. This is a vast literature: for a representative work, see Katherine Bergeron and Philip Bohlman, eds, Disciplining Music: Musicology and Its Canons (Chicago: University of Chicago Press, 1992); for a summary, Alastair Williams, Constructing Musicology (Aldershot: Ashgate, 2001). Our sense is, nonetheless, that the broadening of curriculum and canon is limited: popular and non-Western musics, popular music studies and ethnomusicology tend to occupy the peripheries of TM degree programmes, which continue to evidence a predominantly historicist orientation.

97 To indicate the range: as well as the 'post-1992' universities, influential MT degrees have developed in Russell Group universities including Manchester, Birmingham, and, included in our study, Queen's University Belfast, Edinburgh, and York, also a 1960s university. 
Thus, regardless of the rapid growth in MT student numbers and the attempted reform by the MT degrees of what counts in terms of curriculum and canon, and thus their attempted redefinition of cultural capital in music, the negative interpretation suggests that the MT degrees and their curricula are not experiencing a marked rise in legitimacy. Moreover, in terms of absolute size of student population, and thus likely cultural impact, the TM degrees still dwarf the MT degrees - although the gap is lessening. ${ }^{98}$ From this perspective, the definition of cultural capital in music may well continue to be defined by the Western art music-focused curricula of the TM degrees, so that cultural capital will remain concentrated in those degrees, with the effect that MT graduates will not experience significant social mobility as a result of their university trainings. ${ }^{99}$ At the same time, the UCAS data on TM degrees, and the demographics and A-level results going into them, suggest that this aspect of the field is relatively static or self-reproducing, or even resists change. That the TM degrees may resist change is also plausible in light of the wider cultural changes charted in Born's fieldwork, discussed below, which suggest that effort may be required to stay still (as it were) in terms of the curriculum and canon that they propound.

\section{Positive interpretations}

Alternatively, it is possible to give more positive interpretations of our data. In this light, the growth in MT degrees opens out potentially progressive sets of developments for their student populations. They include, but are not limited to, the contribution of MT degrees in conjunction with other institutional changes to reconfiguring the musical canon and reworking the boundaries between art and popular musics, thereby auguring potentially far-reaching changes in the musical field.

A first observation is that along with their broader social access, MT degrees arguably cultivate new vocational strengths for students of music, beyond those offered by TM degrees. Because of their interdisciplinary engagement with aspects of science and technology, MT degrees provide the basis for a wider range of potential employment and training opportunities than the TM degrees, including an array of technical and professional jobs in music, audio, media/new media, IT, and design. This has immediately to be qualified with reference to the rapid growth in MT student numbers, pointing (once again) to the risks of overproduction of MT graduates, along with the problematic gendering of this population.

A second potential series of effects of the growth in MT degrees points to the interrelations between educational, aesthetic, and institutional change, as well as the changing boundaries between art and popular musics. They arise because the MT degrees, in conjunction with

98 Between 1994-95 and 2011-12, the TM degrees saw an overall growth of 150 per cent, with student numbers expanding from $c .7,500$ to $c .19,000$ p.a. In the same period, the MT degrees saw a $c .1400$ per cent growth in student numbers, from $c .545$ to $c .8,165$ p.a.

99 An instructive finding, supporting this interpretation, comes from Coulangeon's work on contemporary France. He finds that, despite evidence for increasingly omnivorous practices among certain higher social classes (see note 86), it is traditional forms of highbrow cultural capital that convert most readily into upward social mobility. See Philippe Coulangeon, 'The Omnivore and the "Class Defector": Musical Taste and Social Mobility in Contemporary France', Notes and Documents, 2013-03 (Paris: OSC, Sciences Po/CNRS, 2013). 
other cultural-historical processes, synergistically fuel transformations both in the musical canon and in the current institutionalized settlement between 'high' and 'low' in music. This occurs as a consequence of their curricula, specifically their modernizing break with the historicist basis of TM degrees, and their orientation towards a spectrum of twentiethand twenty-first-century electronic and computer-based art and popular musics, along with aspects of sound art.

Moreover, while they centre aesthetically on electroacoustic music, the MT degrees also participate in a wider struggle over the changing canon in electronic and computer musics partly under the pressure of student interest and student identification. This is very clear in Born's ethnographic fieldwork. It is driven in part by the need to appeal to the students' own musical tastes for such genres as hip hop, electronica, house, jungle, garage, drum'n'bass, dubstep, glitch, and noise. But the evolving MT curriculum also reflects shifting musical orientations among the generation teaching the MT students, especially those under about fifty years of age who grew up in an era in which punk, post-punk, new wave, industrial and related avant-garde popular musics, along with the techno and house genres associated with rave, were crucial reference points as they developed alongside the electroacoustic and computer art music repertoires. Indeed for this generation, arguably, the two are experienced as inextricably related, a finding supported by Born's fieldwork. A further dynamic fuelling these shifts stems from the emergence over recent decades of lively, increasingly audible and visible non-academic electronic and digital music scenes that, since the end of the 1990s, have been recognized by the circuit of international prizes and festivals and that exert escalating pressure for aesthetic and ideological change, beyond academic electroacoustic and computer music. $^{100}$

The spread of musics that the MT students are being taught therefore differs considerably from the acoustic music canon of the TM degrees: it necessarily centres on electronic and computer musics dating from the mid-twentieth century onwards; and this appears to make it easier, and arguably necessary, to elide the long-standing boundaries between art and popular musics: from Varèse to the Beatles, Cage to John Cale, Stockhausen to Aphex Twin, Xenakis to Hendrix. This aesthetic opening happens more and less voluntarily or enthusiastically: our research on MT degrees in Montréal, for example, suggests greater reluctance than in the UK degrees to crossing the art-popular divide in teaching, and more condescension and ambivalence on the part of key MT university faculty. Moreover, even in the British MT degrees, popular musics enter the curriculum as a fruitful margin, or as a specialist subject treated in a similar way to the TM canon - for example, as an option course, in one research site, on the Beatles.

100 A turning point was the award of the 1999 Prix Ars Electronica for digital musics to Aphex Twin and the Mego label. The Jury Statement, by Kodwo Eshun, criticized the hegemonic 'ancien regime of [academic] electroacoustic music', charging it with 'undeserved authority at the cost of cultural irrelevance'. Two influential articles gave a broadly similar analysis: Bob Ostertag, 'Why Computer Music Sucks', Resonance 5/1 (1996), 2, and Kim Cascone, 'The Aesthetics of Failure', Computer Music Journal 24/3 (2000). The Jury Statement is available at: http://90.146.8.18/en/archives/prix'archive/prixJuryStatement.asp?iProjectID=2598 (accessed June 2014). See also Valiquet, 'The Digital is Everywhere', chs 2 and 3. 
In the positive interpretations, then, as a result of the growing legitimation of those musics propounded by the MT degrees, and how they catalyze both marked shifts in the curricula of music in HE and incipient transformations in the electronic and computer music canon, students going through the MT degrees may enter with lower cultural capital, along with their lower social class position; but they nonetheless gain particular kinds of cultural capital in music as a result of their degree training - a very different kind of cultural capital in music, to be sure, than that accumulated by students taking the TM degrees.

Two further logical questions, both to do with the potential consequences of the rapid expansion of the MT student population, and both strenuously departing from the negative interpretation, then arise. First, if the MT degrees represent a growing trend in music in HE in Britain, then a key question is whether their expansion and student popularity will lead to their growing influence on the TM degrees. Indeed it is plausible that the nature of the musical canon as currently institutionalized in the higher status TM and conservatoire degrees might pluralize to include, or might converge with, the emergent canons of the MT degrees; ${ }^{101}$ and if this occurs, then what constitutes cultural capital in music is likely also to evolve. And second, given a changing configuration of cultural capital in music, might the students who graduate from MT degrees actually be becoming ascendant in terms of the kinds of cultural capital in music they accumulate from higher education? Will this eventually eclipse the historicist cultural capital bestowed by the TM degrees? The result might be that students coming out of the MT degrees become bearers of greater cultural capital than at present. And if so, what does this augur more generally for changes in the future relations between social class and cultural capital in music?

But a third crucial question follows this hypothetical scenario: is the cultural capital in music bestowed by the MT degrees likely to be convertible into other forms of capital economic and social capital - that are equally or more formative of students' eventual social class position? ${ }^{102}$ Or are we likely instead to witness an expansion in the guise of the MT graduate population of what Bourdieu described as the 'dominated fraction of the dominant class' - that is, artists and intellectuals with considerable cultural capital but little economic and other forms of capital? ${ }^{103}$ And might this population constitute or fuel in their growing numbers, as predicted by Garnham and Miège, a reserve army of labour in music?

101 Such a convergence is difficult to discern. In Manchester University's undergraduate music degree, TM and MT coexist as streams within a single degree structure. But in Huddersfield University, although previously separate departments of Music and Music Technology have recently been combined, a spectrum of differentiated undergraduate degrees including Music and Music Technology are retained.

102 See note 99 for a contemporary French perspective on this question.

103 Pierre Bourdieu, Distinction: A Social Critique of the Judgement of Taste (Cambridge, MA: Harvard University Press, 1984), 489. For further explanation, see Simon Stewart, A Sociology of Culture, Taste and Value (Basingstoke: Palgrave, 2014), 79. 


\section{Institutionalization, legitimation, and the production of consumption: against conceptual fragmentation}

To make greater sense of the foregoing distinctive scenarios, it is important at this point to widen the lens beyond the universities and acknowledge larger shifts signalling a transition in the institutionalization of the structure of value and legitimation in music alluded to earlier. Our research shows that the momentum for change in the contemporary music repertoire does not stem only from the growth of the MT degrees. In recent years, the key cultural institutions for contemporary music in Britain - the BBC in the guise of the Proms and Radio 3's new music programmes, Arts Council England through its new music proxy, Sound and Music, and major and emergent festivals like the Huddersfield Contemporary Music Festival and the London Contemporary Music Festival - have all moved in the direction of mainstreaming and beginning to canonize three broad lineages that had hitherto been considered marginal or alternative to the dominant post-Second World War lineages of post-serialist, spectral, and electroacoustic composition. The three broad lineages are: American, British, and European experimental musics; free improvised musics; and sound art. At the same time, a fourth incipient lineage is being recognized: a host of burgeoning electronic and digital music genres that cross over between academic and non-academic, art and popular musics, among them ambient, glitch, microsound, noise, experimental electronica, live coding, live electronics, and extreme computer music. Why are these emergent changes - at once aesthetic, educational, and cultural-institutional happening?

On the part of the music sector, they derive to some extent from long-standing political criticisms of elitism in public provision of music and the arts, allied to arguments about the need to justify public funding of the arts, to boost 'cultural participation' and cultivate new audiences who had previously been excluded through audience 'development'. These shifts were associated with the rise from the mid-1990s of policies stipulating that publicly funded arts organizations must measure their capacity to engender 'public value' by assessing the 'social and economic impact' of their work, in part by engaging in various forms of audience research. ${ }^{104}$ But they derive also from a parallel drive among the main music institutions to cultivate younger audiences for new music - which makes them subject to similar pressures for change as the MT degrees. Indeed, it is plausible to see the motivations driving this historical dynamic in recent decades as culturally democratic ones on the part of key public cultural institutions, with effects that are particularly responsive to generation (and age) as well as social class.

104 On the 'public value' paradigm and its influence in Arts Council England, see Michelle Reeves, Measuring the Social and Economic Impact of the Arts (London: ACE, 2002); Dave O’Brien, Measuring the Value of Culture (London: DCMS, 2010). For critical historical analyses, see David Lee et al., "'The Public gets what the Public Wants"? The Uses and Abuses of "Public Value" in Contemporary British Cultural Policy', International Journal of Cultural Policy 17/3 (2011); and Hewison, Cultural Capital, ch. 3. For analogous developments in the BBC, see Georgina Born, Uncertain Vision (London: Vintage, 2005), ch. 7. These complex historical developments responded to political currents from both right and left, with roots at least in the 1980s. 
But the impetus for change is also specifically musical: the ongoing unfolding, evolution, and intermingling of major aesthetic lineages. ${ }^{105}$ In this regard, the main new music institutions are rapidly recalibrating the contemporary Western art music canon: they are engaged in elevating the experimental music lineage over the post-serialist avant-garde, to which it was previously secondary, endowing emblematic experimental composers and musicians with canonic status equal to Boulez, Stockhausen, or Carter. This is evident, for example, at the Huddersfield Contemporary Music Festival, which is in partnership with the other bodies mentioned (the BBC, ACE, Sound and Music, and so on), and where figures such as Cage, Feldman, Tudor, Wolff, Tenney, Alvin Curran, James Dillon, Brian Eno, and Evan Parker have been to the fore in recent programming. The doyen of free improvisation, saxophonist Evan Parker, is a case in point: in earlier decades an outstanding figure in a thenalternative international scene, in recent years he has been championed by a series of bodies and festivals linked to leading MT universities. While the free improvisation scene is identified historically with an ideology that rejects Western art music's ontology of the work, that there is little breach with prevailing canonic modes of valorization and legitimation is evident in how Parker's astonishing virtuosity as a performer makes it possible for him to be equated with leading composers and thus recognized within existing Western art music discourses of value. It would therefore be a mistake to see these moves by the major contemporary music institutions - the BBC, ACE, Sound and Music, and so on - as non- or anti-canonic. Rather, these bodies are energetically engaged in producing a transition to a new canonic regime, in some cases incorporating practices antithetical to the work ontology, as though there was no tension. It would also be a mistake to see these shifts as without conflict: they are, rather, riven with interests and struggles over what counts and what does not (see below).

A final element in this picture is the rise of sound art, a diverse area of practice that developed in recent decades outside the music institutions under the auspices of the visual arts, and which has begun to register as an element in the curricula of the MT degrees. The result is an alternative genealogy both to the post-Second World War avant-garde and to experimental music (albeit with links to the latter). Certain MT degrees have responded to the rising profile of sound art by including 'sound art' or 'sonic arts' in their titles and, to varied extents, in their curricula; while the London College of Communication, part of the University of the Arts, London, inaugurated what has become the heartland degree. ${ }^{106}$ These developments have accompanied a growing legitimation of and public profile for sound art, such that a convergence of a kind has occurred between sound art and the electroacoustic and experimental music lineages - a convergence concretized when, in spring 2012, a major political conflict erupted between these lineages and representatives of British acoustic

105 On the changing articulation of major aesthetic lineages and the challenges posed thereby to musicology, see David Clarke, 'Elvis and Darmstadt, or: Twentieth-Century Music and the Politics of Cultural Pluralism', Twentieth-Century Music 4/1 (2007); Georgina Born, 'For a Relational Musicology: Music and Interdisciplinarity, Beyond the Practice Turn', Journal of the Royal Musical Association 135/2 (2010).

106 See www.arts.ac.uk/lcc/courses/undergraduate/ba-hons-sound-arts-and-design/, www.arts.ac.uk/lcc/courses/ postgraduate/ma-sound-arts/ and related degrees; and the linked LCC-based research centre CRiSAP (Creative Research into Sound Arts Practice): www.crisap.org. 
composition over the naming and remit of the key public funding body for new music, Sound and Music. ${ }^{107}$ This conflict signalled a growing coalition among electroacousticexperimental-improvisation-sound art proponents in their struggle with contemporary inheritors of post-Second World War acoustic composition, whose diverse works connect to the lineages of early twentieth-century musical modernism and hence, arguably, to the primarily historicist, acoustic canon espoused by the TM degrees. The MT degrees therefore form part of a much wider reconfiguration of British contemporary music that includes other key cultural institutions and that entails struggles - for recognition and legitimation, as well as economic subsidy - over the reshaping of the prevailing canon of twentieth-century art music. Yet despite the contestation, contemporary acoustic composition retains considerable traction and status with the $\mathrm{BBC}$, conservatoires and concert organizations; so the various lineages continue an uneasy coexistence, competing for status, legitimation, and funding.

An additional interpretation follows: it might be summarized as 'the musical field as multiverse'. This would suggest that we are seeing not so much a replacement of one canonic nexus (the historicist curricula of TM degrees) by another (the contemporary curricula of MT degrees), nor their convergence, but a proliferation and diversification of the very forms of cultural capital in music. This scenario foresees a musical field in which various ideologies of musical value and legitimation coexist, associated with particular aesthetic nexuses and institutional formations, but with no necessary relationship between them; and in which their eventual relative status, educational reach, and institutionalized forms are as yet unknowable. This points to the potential for a sustained fragmentation: it is a conception of the field as a concatenation of incommensurable forms of musical-cultural capital - a musical 'multiverse'.

Overall, whatever the future evolution of the relationship between the two kinds of music degrees, and between them and the larger musical field, a final overarching question raised by this article concerns the articulation between the earlier research on music consumption and class (by Bourdieu, Peterson, Bennett et al., Savage and Gayo) and the research presented here on social class and gender in relation to music in HE and its influence on musicians' training - that is, on the production both of music producers and of educated consumers. The student output of the MT degrees are musicians who may or may not enter the worlds of professional music-making and who may remain amateur and/or unemployed musicians; yet in all cases, these students will be music consumers and quite possibly, through their sustained, 'independent', and committed practices as amateurs or 'prosumers', particularly influential consumers, helping to reshape the musical future, including its aesthetic and

107 The crisis was initiated by an 'open letter to Sound and Music' released to the British press on 27 March 2012 signed by some 250 leading acoustic composers, among them Sir Harrison Birtwistle, Sir Peter Maxwell Davies, Julian Anderson, George Benjamin, and Michael Finnissy. The letter complained that Sound and Music had 'abandoned virtually all of the long-established and constructive activities of [the earlier bodies that it had replaced], largely in favour of a bland and unfocused endorsement of "sound art" and the promotion of relatively fringe activities which [have] little or no connection with the mainstream'. This began a tense, sometimes acrimonious debate between these representatives of 'notated and modern composition' and a coalition of experimental and electracoustic composers, sound artists and improvisers. See the original letter: www.holstfoundation.org/index.php?pr=Open Letter to 'SAM' and ACE; and the coalition reply: www.chrisswithinbank.net/2012/04/response-to-letters-to-sam-ace/. 
institutional forms. ${ }^{108}$ So we propose that something of what we have uncovered in this study may also augur, or may be affecting, broader changes in music consumption in the UK. The generations coming out of MT degrees now span almost two decades - from those born around 1980 to those born in the late 1990s. The huge expansion of the MT degrees may, then, be having real effects on the shifting configuration of musical tastes and music consumption in Britain; and the student outputs of the degrees, c. 8,000 graduating a year in the last years of our sample, will be exerting pressures on the correlations seen by previous writers on music and class in Britain. To put it crudely, the relative market share of the TM degrees has shrunk, while the MT students fuel demographic taste formations in music of considerable scale and with real audibility. Moreover on leaving university, through their practices, MT graduates help performatively to propagate the aesthetic changes staged by the degrees in which they have participated. The MT degrees are surely themselves formative, in small but influential ways, of wider movements both in taste formations and in the relations between music and social class.

The production of music producers by music degrees influences consumption - including the MT degrees' mediation, through their cultivation of digital literacies, of the changing boundary between the production and consumption of music, and of the massively expanding populations of skilled amateurs. But this crucial element - the mass formation of amateurs, unemployed musicians, consumers and 'prosumers' - has been missing from the existing debates. Missing also, as we have tried to indicate, has been a conceptualization of consumption as but one element in a larger socio-musical ecology in which production, education (the production of producers and consumers) and consumption, along with largescale aesthetic changes and their evolving institutionalization, are intrinsically and recursively interrelated - albeit always in distinctive ways, catalyzed by particular historical conditions. A final methodological message of this study, evident in the analytical span of this article, is therefore that future research will need to resist conceptual fragmentation by addressing how shifts, for example, in music in HE both influence and are affected by wider changes in the production and consumption of music, as these developments in turn mediate and are mediated by wider musical, technological, cultural, social, and political transformations. By decontextualizing certain key findings, notably those related to music consumption and class, previous research risks misidentifying how changing taste formations relate to institutionally sanctioned valorizations of cultural capital in music, as they in turn may be static or changing - as we have indicated for Britain today. ${ }^{109}$

108 Indeed, it is this category of musician - independent, non-academic musicians - who promoted some of the significant aesthetic changes in electronic and digital musics registered previously: see note 100 .

109 The overall attempt in this research to discern how social relations of gender and class both mediate and are mediated by music, and, in addition, how this evolving two-way relationship between gender, class, and music is itself mediated by wider institutional changes - notably, the development of the MT degree sector - is one that is captured theoretically and methodologically by Born's identification of four mutually-articulating 'planes' of social mediation of music. In this study, third plane social mediations of music, by gender and class, are also enmeshed in, and influenced by, fourth plane social mediations - that is, by music's changing institutional conditions. On the general theory of musical mediation see Georgina Born, 'On Musical Mediation: Ontology, Technology and 


\section{Conclusions}

The optimistic tone of some accounts of the omnivore thesis in cultural sociology - which suggests 'that there is a sector of the population of western countries who do and like a greater variety of forms of culture than previously, and that this broad engagement reflects emerging values of tolerance'110 - is matched by optimism on the part of some of those researching gender in music. Thus, twenty years ago, Chris Comber, David Hargreaves, and Ann Colley concluded their study of 'Girls, Boys and Technology in Music Education' on a hopeful note: "In the earliest days of the "computer revolution" there was much discussion of the potential of IT to dissolve the barriers between "masculine" technology and "feminine" creativity. That dream of a gender-free technology may yet be within reach. ${ }^{111}$ As we have shown in this article, however, in relation to music, social class, and gender in the UK, such optimism may be misplaced - or premature.

Yet two important qualifications must be acknowledged. We are aware that the period covered by our UCAS data set (2007-12) may be exceptional, and in two ways. First, it may be a particular 'divergent' period with respect to the bifurcation of the two degrees, TM (traditional music) and MT (music technology), into which our UCAS data fall, and on which our analysis has been founded. There are signs that certain British university music departments are bringing these two sides of the curriculum into closer relation, or integrating them into the same degree. ${ }^{112}$ Second, a limitation of the study is that our data end just before the British government's introduction in autumn 2012 of undergraduate tuition fees of $£ 9,000$ per year. Although recent UCAS data suggest that this change has not significantly affected undergraduate student recruitment or demographics (see note 34), the longer-term effects of this development remain uncertain. It seems plausible that the introduction of higher fees could deter students coming from lower social class backgrounds from enrolling on all degrees, including MT degrees. These recent developments are therefore likely to be consequential for our analysis but, regrettably, they lie outside the scope of this study. We would need to purchase UCAS data for subsequent years to understand the impact these changes are having on the influx particularly of young white men of lower social class background into the universities, drawn by innovative non-traditional music degrees that offer them, without regard to traditional musical literacy, a serious training in creative music practices and related skills. Yet despite these qualifications, the study captures an important

Creativity', Twentieth-Century Music 2/1 (2005), and on the theory of four planes of social mediation of music, 'Music and the Materialization of Identities', Journal of Material Culture 16/4 (2011), and 'Music and the Social', in The Cultural Study of Music: A Critical Introduction, ed. Martin Clayton, Trevor Herbert and Richard Middleton (London: Routledge, 2012). For a sustained application of Born's social mediation theory to music and gender, see the 'Introduction' to Born and Devine, 'Gender, Education and Creativity'.

110 This concise summary of the omnivore thesis is taken from Alan Warde et al., 'Understanding Cultural Omnivorousness: Or, the Myth of the Cultural Omnivore', Cultural Sociology 1/2 (2007), 143.

111 Chris Comber et al., 'Girls, Boys and Technology in Music Education', British Journal of Music Education 10/2 (1993), 133.

112 See note 101 . 
period and provides an analysis that can fuel reflection among the community engaged in the provision of music in Higher Education.

Fifteen years after the introduction of the Music Technology A-level, at a point when the first generation of music technology students is now mentoring and educating the next, ${ }^{113}$ we have presented the following picture. TM degrees tend to draw students with higher social class profiles (and fewer black and minority ethnic students) than the British national average, while the gender profile matches the wider student population. The demographic of MT degrees, by contrast, is overwhelmingly male and lower in terms of social class profile (and slightly more ethnically diverse, although still predominantly white). We have suggested that it is possible to interpret these developments in different ways.

From one perspective, MT degrees can be understood as a fulfilment of almost twenty years of educational reform: technology and, to a variable extent, science have become central to music in HE, institutionalizing a strong interdisciplinarity. This has engendered a widening of access and a huge growth in student numbers, and has offered a quite different vocational orientation to the TM degrees. In this light, the growth in MT degrees - with their interdisciplinary embrace of technology and science, their less elitist and more experimental musical orientation, and their broader social access and vocational strengths - represents a crucial transition away from the predominantly historicist orientation of TM degrees. They aspire to train students who are equipped for and can be inserted into a host of new technical and professional occupations in the burgeoning, intersecting fields of music, sound and audio, IT, design, and the other media and arts. In short: modernization, and potentially hope for the future. But difficult questions remain, particularly with regard to the potential overproduction of students from the MT degree sector. Simply put, where will all these graduates go?

In another light, the TM and MT degrees seem to participate in feedback loops whereby existing ideologies of gender and technology, and social class differences, are being reinforced or even amplified through music in HE. This is not a new phenomenon. ${ }^{114}$ But there is an argument to be made that digital technologies inflect these established processes in particular ways. We would therefore argue against the common sense of our time, in which the digital mediation of culture is often thought to have ushered in 'an era of greater abundance and choice for consumers' and 'a more democratised set of production relations.' ${ }^{115}$ While such interpretations may seem persuasive - a world in which the exclusions and rigidities of vertical integration appear to give way to the ostensible liveliness of disintermediation, where the eclecticism and mobility of digital files participate in the 'consecration of incoherence', and where shuffle functions and recommendation algorithms afford new modes of musical

113 Boehm, 'The Discipline That Never Was'.

114 See Théberge, Any Sound, 182-3; Bull, 'The Musical Body'; Dibben, 'Socio-Cultural and Learning Experiences'; Green, Music, Gender, Education.

115 From David Hesmondghalgh, 'The Digitalisation of Music', in Creativity, Innovation and the Cultural Economy, ed. Andy Pratt and Paul Jeffcutt (London: Routledge, 2009), 57, who is strongly criticizing the underlying ideology. See also Théberge, 'Digitalization'. 
discovery $^{116}$ - our research suggests a more cautious reading. While it is doubtless true, to a certain extent, that digital mediation affords vectors of musical encounter (and thus of aesthetic experience and practice) that are less encumbered by the institutionalized, historicist spheres of influence that characterized pre-digital channels of production, consumption, and circulation, in identifying the bifurcating demographics of TM and MT degrees we invite careful reflection on the socio-musical formations which, unchecked, will be created through the currents in music education that we have identified. Given the profound shifts charted in this article, at stake are nothing less than the future relations between music, gender, and social class in the UK.

\section{Bibliography}

Abeles, Hal. 'Are Musical Instrument Gender Associations Changing?' Journal of Research in Music Education 57/2 (2009), 127-39.

Armstrong, Victoria. Technology and the Gendering of Music Education. Farnham: Ashgate, 2011.

Atkinson, Will. 'The Context and Genesis of Musical Tastes: Omnivorousness Debunked, Bourdieu Buttressed'. Poetics 39 (2011), 169-86.

Bayton, Mavis. Frock Rock: Women Performing Popular Music. Oxford: Oxford University Press, 1997.

BBC. 'Census Shows Rise in Foreign-Born'. 11 December 2012. www.bbc.co.uk/news/uk-20687168 (accessed 22 June 2015).

Beer, David. 'The Iconic Interface and the Veneer of Simplicity: MP3 Players and the Reconfiguration of Music Collecting and Reproduction Practices in the Digital Era'. Information, Communication \& Society 11/1 (2008), 71-88.

Beer, David and Mark Taylor. 'The Hidden Dimensions of the Musical Field and the Potential of the New Social Data'. Sociological Research Online 18/2 (2013), online.

Behr, Adam. 'Cultural Policy and the Creative Industries', in The Routledge Reader on the Sociology of Music, ed. John Shepherd and Kyle Devine. New York: Routledge, 2015. 277-86.

Bennett, Tony, Mike Savage, Elizabeth Silva, Alan Warde, Modesto Gayo-Cal and David Wright. Culture, Class, Distinction. London: Routledge, 2009.

Bergeron, Katherine and Philip Bohlman, eds. Disciplining Music: Musicology and Its Canons. Chicago: University of Chicago Press, 1992.

Bijsterveld, Karin. Mechanical Sound: Technology, Culture, and Public Problems of Noise in the Twentieth Century. Cambridge, MA: MIT Press, 2008.

Blickenstaff, Jacob Clark. 'Women and Science Careers: Leaky Pipeline or Gender Filter?' Gender and Education $17 / 4$ (2005), 369-86.

Boehm, Carola. 'The Thing About the Quotes: "Music Technology" Degrees in Britain'. Proceedings of the International Computer Music Conference. New Orleans, 2006.

—_. 'The Discipline That Never Was: Current Developments in Music Technology in Higher Education in Britain'. Journal of Music, Technology and Education 1/1 (2007), 7-21.

Boltanski, Luc. On Critique: A Sociology of Emancipation. Cambridge: Polity, 2011.

116 For various articulations and critiques of these ideas, see Steve Jones 'Music that Moves: Popular Music, Distribution and Network Technologies', Cultural Studies 16/2 (2002); David Beer, 'The Iconic Interface and the Veneer of Simplicity: MP3 Players and the Reconfiguration of Music Collecting and Reproduction Practices in the Digital Era', Information, Communication and Society 11/1 (2008); Michael Bull, Sound Moves: iPod Culture and Urban Experience (London: Routledge, 2008); Mark Rimmer 'Beyond Omnivores and Univores: The Promise of a Concept of Musical Habitus', Cultural Sociology 6/3 (2012), 303; Nick Seaver, 'Algorithmic Recommendations and Synaptic Functions', Limn 2 (2012), online; David Beer and Mark Taylor, 'The Hidden Dimensions of the Musical Field and the Potential of the New Social Data', Sociological Research Online 18/2 (2013), online; Eitan Wilf, 'Toward an Anthropology of Computer-Mediated, Algorithmic Forms of Sociality', Current Anthropology 54/6 (2013). The idea of a 'consecration of incoherence' is adapted from Will Straw, 'The Consecration of Musical Incoherence', Kinephanos 2/1 (2011). 
Boltanski, Luc and Eve Chiapello. The New Spirit of Capitalism. London: Verso, 2005.

Bolton, Paul. 'Education: Historical Statistics'. House of Commons Library, 27 November 2012.

Born, Georgina. Rationalizing Culture: IRCAM, Boulez, and the Institutionalization of the Musical Avant-Garde. Berkeley: University of California Press, 1995.

- 'On Musical Mediation: Ontology, Technology and Creativity'. Twentieth-Century Music 2/1 (2005), 7-36.

. Uncertain Vision: Birt, Dyke and the Reinvention of the BBC. London: Vintage, 2005.

. 'For a Relational Musicology: Music and Interdisciplinarity, Beyond the Practice Turn'. Journal of the Royal Musical Association 135/2 (2010), 205-43.

— . 'Listening, Mediation, Event: Anthropological and Sociological Perspectives'. Journal of the Royal Musical Association 135/1 (2010), 79-89.

. 'The Social and the Aesthetic: For a Post-Bourdieuian Theory of Cultural Production'. Cultural Sociology 4/2 (2010), 171-208.

—_. 'Music and the Materialization of Identities'. Journal of Material Culture 16/4 (2011), 376-88.

- ' 'Music and the Social', in The Cultural Study of Music: A Critical Introduction, ed. Martin Clayton, Trevor Herbert and Richard Middleton. London: Routledge, 2012. 261-74.

—. 'Musico-Material Experiments: Ontological Politics in Digital Art Musics'. Presented at Retheorising the Mutual Mediation of Technology and Aesthetics: The Case of Music, University of Oxford, October 2012.

—. 'Creative Destruction: Electronic and Digital Art Musics in the UK in the Era of Creative Industries and Creative Economy'. Presented at Music and Digitisation: Industry, Institutions and Livelihoods, University of Oxford, March 2013.

- 'Lecture 5 - Ontologies and Interdisciplinarities', The Bloch Lectures, Department of Music, University of California, Berkeley, 3 November 2014.

Born, Georgina and Kyle Devine, eds. Contemporary Music Review (Special issue: 'Gender, Education and Creativity in Digital Music and Sound Art') (forthcoming 2015).

Bourdage, Monique. "'A Young Girl's Dream": Examining the Barriers Facing Female Electric Guitarists'. IASPM@Journal 1/1 (2010).www.iaspmjournal.net/index.php/IASPM Journal/article/view/334/557 doi:10.5429/2079-3871(2010)vli1.1en (accessed 22 June 2015).

Bourdieu, Pierre. Distinction: A Social Critique of the Judgement of Taste. Cambridge, MA: Harvard University Press, 1984.

—. 'The Forms of Capital', in Handbook of Theory and Research for the Sociology of Education, ed. John Richardson. New York: Greenwood, 1986. 241-58.

Bradby, Barbara. 'Sampling Sexuality: Gender, Technology and the Body in Dance Music'. Popular Music 12/2 (1993), 155-76.

British Labour Party. New Labour, New Life for Britain. London: Labour Party, 1996.

—. Britain Forward Not Backward: The Labour Party Manifesto, 2005. London: Labour Party, 2005.

Brown, Katherine Butler. 'The Social Liminality of Musicians: Case Studies from Mughal India and Beyond'. Twentieth-Century Music 3/1 (2007): 13-49.

Bull, Anna. 'The Musical Body: How Gender and Class are Reproduced Among Young People Playing Classical Music in England'. PhD diss., Goldsmiths College, University of London, 2014.

Bull, Michael. Sound Moves: iPod Culture and Urban Experience. London: Routledge, 2008.

Caputo, Virginia. 'Add Technology and Stir: Music, Gender and Technology in Music Classrooms'. Quarterly Journal of Music Teaching and Learning 4/4 (1993-94), 85-90.

Cascone, Kim. 'The Aesthetics of Failure'. Computer Music Journal 24/3 (2000), 12-18.

Chadabe, Joel. Electric Sound: The Past and Promise of Electronic Music. Upper Saddle River, NJ: Prentice Hall, 1997.

Chan, Tak Wing and John Goldthorpe. 'Social Stratification and Cultural Consumption: Music in England'. European Sociological Review 23/1 (2007), 1-19.

Citron, Marcia. Gender and the Musical Canon. Cambridge: Cambridge University Press, 1993.

Clarke, David. 'Elvis and Darmstadt, or: Twentieth-Century Music and the Politics of Cultural Pluralism'. TwentiethCentury Music 4/1 (2007), 3-45.

Cockburn, Cynthia. Brothers: Male Dominance and Technological Change. London: Pluto Press, 1983.

Cohen, Nicole. 'Cultural Work as a Site of Struggle: Freelancers and Exploitation'. tripleC 10/2 (2012), $141-55$.

Cohen, Sara. 'Men Making a Scene: Popular Music and the Production of Gender', in Sexing the Groove: Popular Music and Gender, ed. Sheila Whiteley. New York: Routledge, 1997. 17-34.

Comber, Chris, David Hargreaves and Ann Colley. 'Girls, Boys and Technology in Music Education'. British Journal of Music Education 10/2 (1993), 123-34.

Cooper, Joel. 'The Digital Divide: The Special Case of Gender'. Journal of Computer Assisted Learning 22 (2006), $320-34$. 
Corver, Mark. 'UCAS Analysis Answers Five Key Questions on the Impact of the 2012 Tuition Fees Increase in England', November 2014. www.ucas.com/corporate/news-and-key-documents/news/ucas-analysis-answersfive-key-questions-impact-2012-tuition (accessed 22 June 2015).

Coulangeon, Philippe. 'The Omnivore and the 'Class Defector': Musical Taste and Social Mobility in Contemporary France'. Notes and Documents, 2013-03, Paris: OSC, Sciences Po/CNRS, 2013.

Coulangeon, Philippe and Yannick Lemel. 'Is "Distinction" Really Outdated? Questioning the Meaning of the Omnivorization of Musical Taste in Contemporary France'. Poetics 35/2-3 (2007), 93-111.

Cox, Christoph and Daniel Warner, eds. Audio Culture: Readings in Modern Music. London: Continuum, 2004.

David, Miriam, et al. Widening Participation in Higher Education: A Commentary by the Teaching and Learning Research Programme. TLRP and ESRC, 2008.

Department for Business, Innovation and Skills. 'Participation Rates in Higher Education: Academic Years 2006/2007-2012/2013'. London: Department for Business, Innovation and Skills, 2014.

Devine, Kyle. 'Imperfect Sound Forever: Loudness Wars, Listening Formations and the History of Sound Reproduction'. Popular Music 32/3 (2013), 159-76.

Dibben, Nicola. 'The Socio-Cultural and Learning Experiences of Music Students in a British University'. British Journal of Music Education 23/1 (2006), 91-116.

Diduck, Ryan. 'The 30th Anniversary of MIDI: A Protocol Three Decades On'. Quietus. 22 January 2013. http://thequietus.com/articles/11189-midi-30th-anniversary (accessed 22 June 2015).

Doubleday, Veronica. 'Sounds of Power: An Overview of Musical Instruments and Gender'. Ethnomusicology Forum 17/1 (2008), 3-39.

Dyer, Richard. White. London: Routledge, 1997.

Farrugia, Rebekah. Beyond the Dance Floor: Female DJs, Technology and Electronic Dance Music Culture. Bristol: Intellect, 2012.

Faulkner, Wendy. 'The Technology Question in Feminism: A View from Feminist Technology Studies'. Women's Studies International Forum 24/1 (2001), 79-95.

Ferreira, Giselle. 'Crossing Borders: Issues in Music Technology Education'. Journal of Music, Technology and Education 1/1 (2007), 23-35.

Froehlich, Hildegard and Lucy Green. 'Sociology of Music Education', in The Grove Dictionary of American Music, 2nd edn. New York: Oxford University Press, 2013.

Garner, Richard. 'Treat White Working-Class Boys Like Ethnic Minority'. The Independent, 3 January 2013, online.

Garnham, Nicholas. Capitalism and Communication. London: Sage, 1990.

Gill, John. 'Labour Concedes That It Won't Deliver Its 50\% Target On Time'. Times Higher Education, 17 April 2008, online.

Green, Lucy. Music, Gender, Education. Cambridge: University of Cambridge Press, 1997.

- ' 'Music Education, Cultural Capital, and Social Group Identity', in The Cultural Study of Music: A Critical Introduction, ed. Martin Clayton, Trevor Herbert and Richard Middleton. London: Routledge, 2012. 206-16.

Hallam, Susan, Lynne Rogers and Andrea Creech. 'Gender Differences in Musical Instrument Choice'. International Journal of Music Education 26/1 (2008), 7-19.

HEFCE. 2005. Young Participation in Higher Education.

- 2010. Trends in Young Participation in Higher Education: Core Results from England.

Henley, Darren. The Importance of Music: A National Plan for Music Education. London: Department for Education, 2011.

Hennion, Antoine. 'Those Things That Hold Us Together: Taste and Sociology'. Cultural Sociology 1/1 (2007), 97-114.

—_. 'The Price of the People: Sociology, Performance and Reflexivity', in Cultural Analysis and Bourdieu's Legacy: Settling Accounts and Developing Alternatives, ed. Elizabeth Silva and Alan Warde. London: Routledge, 2010. 117-27.

Hesmondhalgh, David. 'The Digitalisation of Music', in Creativity, Innovation and the Cultural Economy, ed. Andy Pratt and Paul Jeffcutt. London: Routledge, 2009.

- Why Music Matters. Oxford: Blackwell, 2013.

Hewison, Robert. Cultural Capital: The Rise and Fall of Creative Britain. London: Verso, 2014.

Ingleton, Holly. 'Recalibrating Fundamentals of Discipline and Desire through the Automatic Music Tent'. Paper presented at the NIME (New Instruments for Musical Expression) conference, Goldsmiths' College, University of London (July 2014).

Jones, Steve. 'Music that Moves: Popular Music, Distribution and Network Technologies'. Cultural Studies 16/2 (2002), 213-32.

Kahn, Douglas. Noise, Water, Meat: A History of Sound in the Arts. Cambridge, MA: MIT Press, 1999. 
Keightley, Keir. ““Turn it Down!” She Shrieked: Gender, Domestic Space and High Fidelity, 1948-59'. Popular Music 15/2 (1996), 149-77.

Landy, Leigh. Understanding the Art of Sound Organization. Cambridge, MA: MIT Press, 2007.

Latour, Bruno. Science in Action: How to Follow Scientists and Engineers through Society. Cambridge, MA: Harvard University Press, 1987.

- Reassembling the Social: An Introduction to Actor-Network-Theory. Oxford: Oxford University Press, 2005.

Lee, David, Kate Oakley and Richard Naylor. "The Public gets what the Public Wants"? The Uses and Abuses of "Public Value" in Contemporary British Cultural Policy'. International Journal of Cultural Policy 17/3 (2011), 289-300.

Legg, Robert. “'One Equal Music”: An Exploration of Gender Perceptions and the Fair Assessment by Beginning Music Teachers of Musical Compositions'. Music Education Research 12/2 (2010), 141-59.

Leonard, Marion. Gender in the Music Industry: Rock, Discourse and Girl Power. Farnham: Ashgate, 2007.

_. 'Gender and Sexuality', in The Routledge Reader on the Sociology of Music, ed. John Shepherd and Kyle Devine. New York: Routledge, 2015, 181-9.

Manning, Peter. Electronic and Computer Music. Oxford: Oxford University Press, 2013.

Miège, Bernard. 'The Logics at Work in the New Cultural Industries'. Media, Culture and Society 9 (1987), $273-89$. Mueller, John. 'Is Art the Product of Its Age?' Social Forces 13/3 (1935), 367-75.

- The American Symphony Orchestra: A Social History of Musical Taste. Bloomington: Indiana University Press, 1951.

- 'Musical Taste and How it is Formed', in The Routledge Reader on the Sociology of Music, ed. John Shepherd and Kyle Devine. New York: Routledge, 2015. 49-55.

O'Brien, Dave. Measuring the Value of Culture. London: Department of Culture, Media and Sport, 2010.

- Cultural Policy: Management, Value and Modernity in the Creative Industries. London: Routledge, 2014.

O'Connor, Justin. The Cultural and Creative Industries: A Review of the Literature. London: Creative Partnerships, 2007.

—. 'The Cultural and Creative Industries: A Critical History'. Ekonomiaz 78/3 (2011), 24-47.

Oudshoorn, Nelly, Els Rommes and Marcelle Stienstra. 'Configuring the User as Everybody: Gender and Design Cultures in Information and Communication Technologies'. Science, Technology and Human Values 29/1 (2004), 30-64.

Osborne, Peter. Anywhere or Not at All. London: Verso, 2013.

Ostertag, Bob. 'Why Computer Music Sucks'. Resonance 5/1 (1996), 2.

Perry, Emma and Becky Francis. The Social Class Gap for Educational Achievement: A Review of the Literature. Action and Research Centre, 2010.

Peterson, Richard. 'Understanding Audience Segmentation: From Elite and Mass to Omnivore and Univore'. Poetics 21/4 (1992), 243-58.

—. 'Taste as Distinction', in The Routledge Reader on the Sociology of Music, ed. John Shepherd and Kyle Devine. New York: Routledge, 2015. 153-60.

Prieur, Annick and Mike Savage. 'Updating Cultural Capital Theory: A Discussion based on Studies in Denmark and in Britain'. Poetics 39 (2011), 566-80.

Quality Assurance Agency for Higher Education. Music. QAA: Mansfield, 2008.

Rabinow, Paul. Marking Time: On the Anthropology of the Contemporary. Princeton: Princeton University Press, 2008.

Reeves, Michelle. Measuring the Social and Economic Impact of the Arts. London: ACE, 2002.

Rimmer, Mark. 'Beyond Omnivores and Univores: The Promise of a Concept of Musical Habitus'. Cultural Sociology 6/3 (2012), 299-318.

Riska, Elianne. Medical Careers and Feminist Agendas. New York: Walter de Gruyter, 2001.

Ritzer, George and Nathan Jurgenson. 'Production, Consumption, Prosumption: The Nature of Capitalism in the Age of the Digital "Prosumer"'. Journal of Consumer Culture 10/1 (2010), 13-36.

Rodgers, Tara. Pink Noises: Women on Electronic Music and Sound. Durham, NC: Duke University Press, 2010.

—. 'Synthesizing Sound: Metaphor in Audio-Technical Discourse and Synthesis History'. PhD diss., McGill University, 2010.

Rothenberg, Paula, ed. White Privilege: Essential Readings on the Other Side of Racism. New York: Worth, 2011.

Sargent, Carey. 'Playing, Shopping, and Working as Rock Musicians: Masculinities in "De-Skilled" and "Re-Skilled" Organizations'. Gender and Society 23/5 (2009), 665-87.

Savage, Mike. 'The Musical Field'. Cultural Trends 15/2-3 (2006), 159-74.

Savage, Mike and Modesto Gayo. 'Unravelling the Omnivore: A Field Analysis of Contemporary Musical Taste in the United Kingdom'. Poetics 39 (2011), 337-57. 
Seaver, Nick. 'Algorithmic Recommendations and Synaptic Functions'. Limn 2 (2012), online.

Scharff, Christina. Equality and Diversity in the Classical Music Profession. ESRC, 2015.

Schuessler, Karl. 'Social Background and Musical Taste'. American Sociological Review 13/3 (1948), 330-5.

Shepherd, John. 'Music and Male Hegemony', in Music and Society: The Politics of Composition, Performance and Reception, ed. Richard Leppert and Susan McClary. Cambridge: Cambridge University Press, 1987. 151-72.

Solie, Ruth. Musicology and Difference: Gender and Sexuality in Music Scholarship. Berkeley: University of California Press, 1995.

Sterne, Jonathan. The Audible Past: Cultural Origins of Sound Reproduction. Durham, NC: Duke University Press, 2003.

—. 'Bourdieu, Technique and Technology'. Cultural Studies 17/3-4 (2003), 367-89.

Stepulevage, Linda. 'Gender/Technology Relations: Complication the Gender Binary'. Gender and Education 13/3 (2001), 325-38.

Stewart, Simon. A Sociology of Culture, Taste and Value. Basingstoke: Palgrave, 2014.

Straw, Will. 'The Consecration of Musical Incoherence'. Kinephanos 2/1 (2011), 89-94.

Tagg, Philip. 'The Göteborg Connection: Lessons in the History and Politics of Popular Music Education and Research'. Popular Music 17/2 (1998), 219-42.

Taylor, Timothy. 2011. 'The Seductions of Technology'. Journal of Music, Technology and Education 4(2-3), 227-32.

Théberge, Paul. Any Sound You Can Imagine: Making Music/Consuming Technology. Hanover: Wesleyan University Press, 1997.

—. 'Digitalization', in The Routledge Reader on the Sociology of Music, ed. John Shepherd and Kyle Devine. New York: Routledge, 2015. 329-38.

Thompson, Marie. 'Feminizing Noise'. Paper presented at the NIME (New Instruments for Musical Expression) conference, Goldsmiths' College, University of London (July 2014).

UCAS. How Have Applications for Full-Time Undergraduate Higher Education in the UK Changed in 2012. UCAS Analysis and Research, 2012.

Valiquet, Patrick. “"The Digital is Everywhere”: Negotiating the Aesthetic of Digital Mediation in Montréal's Electroacoustic and Sound Art Scenes. DPhil diss., University of Oxford, 2014.

Wajcman, Judy. Feminism Confronts Technology. Cambridge: Polity, 1991.

. 'Feminist Theories of Technology'. Cambridge Journal of Economics 34/1 (2010), 143-52.

Wakeling, Paul and Mike Savage. 'Entry to Elite Positions and the Stratification of Higher Education in Britain'. Sociological Review (forthcoming 2015).

Warde, Alan, David Wright and Modesto Gayo-Cal. 'Understanding Cultural Omnivorousness: Or, the Myth of the Cultural Omnivore'. Cultural Sociology 1/2 (2007), 143-64.

Ware, Vron and Les Back. Out of Whiteness: Colour, Politics and Culture. Chicago: University of Chicago Press, 2002. Whitely, Sheila, ed. Sexing the Groove: Popular Music and Gender. London: Routledge, 1997.

Wilf, Eitan. 'Toward an Anthropology of Computer-Mediated, Algorithmic Forms of Sociality'. Current Anthropology 54/6 (2013), 716-39.

Williams, Alastair. Constructing Musicology. Aldershot: Ashgate, 2001.

Winterson, Julia and Michael Russ. 'Understanding the Transition from School to University in Music and Music Technology'. Arts and Humanities in Higher Education 8/3 (2009), 339-54. 